\title{
NIST PSCR: Economic Impact Analysis
}

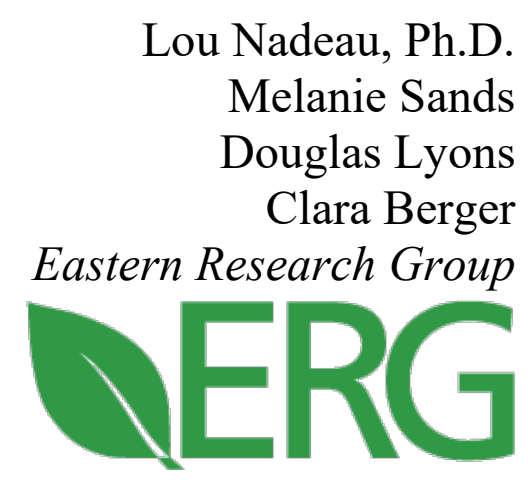

This publication is available free of charge from: https://doi.org/10.6028/NIST.GCR.21-031

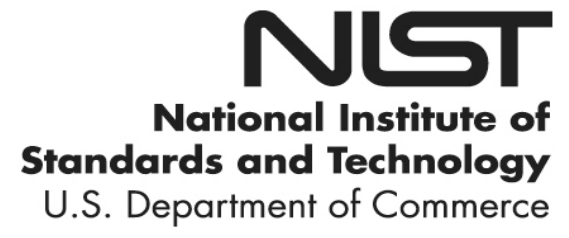




\title{
NIST PSCR: Economic Impact Analysis
}

\author{
Prepared for \\ U.S. Department of Commerce \\ Public Safety Communications Research Division \\ National Institute of Standards and Technology \\ Boulder, CO 80305-3328
}

Lou Nadeau, Ph.D

By

Melanie Sands

Douglas Lyons Clara Berger

Eastern Research Group

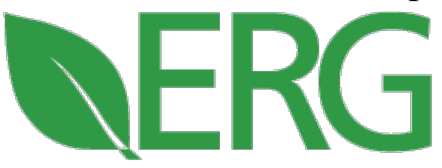

This publication is available free of charge from:

https://doi.org/10.6028/NIST.GCR.21-031

June 2021

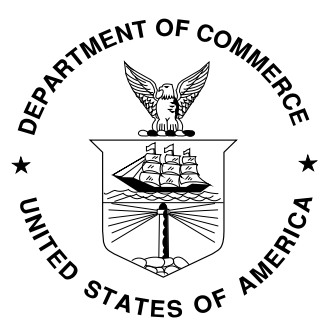

U.S. Department of Commerce Gina M. Raimondo, Secretary

National Institute of Standards and Technology James K. Olthoff, Performing the Non-Exclusive Functions and Duties of the Under Secretary of Commerce for Standards and Technology \& Director, National Institute of Standards and Technology 


\section{Disclaimer}

This publication was produced as part of contract 1333ND21FNB670010 with the National Institute of Standards and Technology. The contents of this publication do not necessarily reflect the views or policies of the National Institute of Standards and Technology or the US Government.

Additionally, certain commercial entities, equipment, or materials may be identified in this document in order to describe an experimental procedure or concept adequately. Such identification is not intended to imply recommendation or endorsement by the National Institute of Standards and Technology, nor is it intended to imply that the entities, materials, or equipment are necessarily the best available for the purpose. 


\begin{abstract}
NIST's Public Safety Communications Research (PSCR) Division is the primary federal laboratory focused on conducting research, development, testing, and evaluation for public safety communications technologies. Their mission is to accelerate communications innovation in support of public safety communities and the citizens they serve. The 2012 Middle Class Tax Relief and Job Creation Act contained landmark provisions for the development and build out of the Nationwide Public Safety Broadband Network (NPSBN) and established The Public Safety Trust Fund (PSTF) to support the design and implementation of the Network. The Act charged the NIST with utilizing up to $\$ 300$ million of PSTF allocations to establish an R\&D program to support the development and deployment of NPSBN from fiscal year 2016 through 2022. In response to the Act's mandate, NIST PSCR developed the Public Safety Innovation Accelerator Program to augment internal research by providing funds to support a range of research mechanisms that span from external grants and cooperative research agreements to prize challenge competitions. The aim of these research mechanisms is to accelerate communications innovation in support of public safety communities and the citizens they serve.

NIST PSCR contracted Eastern Research Group, Inc. (ERG) of Lexington, MA to conduct an economic impact analysis (EIA) of PSTF investments into NIST PSCR's research mechanisms. ERG conducted an EIA using standard economic input-output multipliers from the Bureau of Economic Analysis (BEA) to show how NIST PSCR's research investments translate into broader impacts to states, focusing on new jobs, earnings, value added, and total economic output. The results of the EIA (presented in 2020 dollars) show that NIST PSCR's investment of \$230 million into the suite of research mechanisms generated 4,280 jobs, \$262 million in earnings, \$431 million in value added, and $\$ 513$ million in total economic output.
\end{abstract}

\title{
Key words
}

Communications; economic impacts; economic impact analysis; first responders; public safety; research and development mechanism. 


\section{Table of Contents}

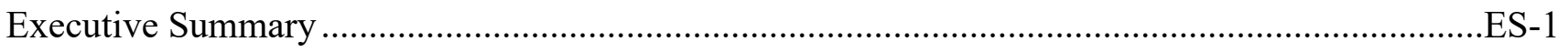

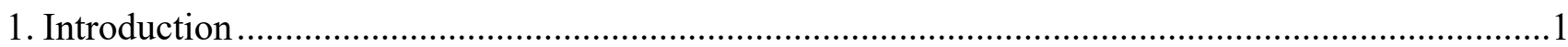

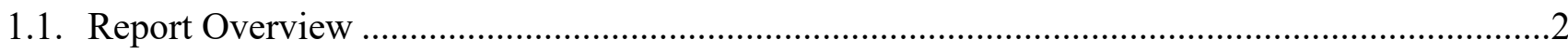

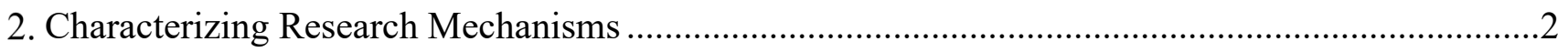

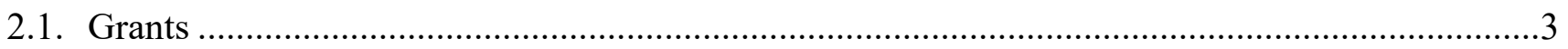

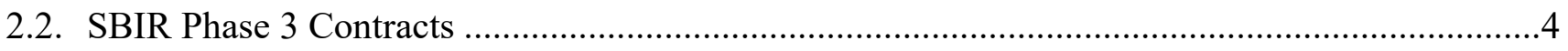

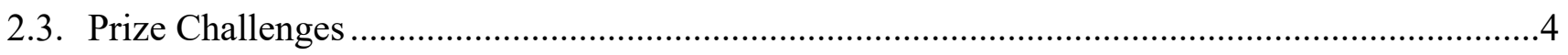

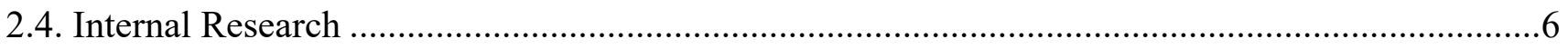

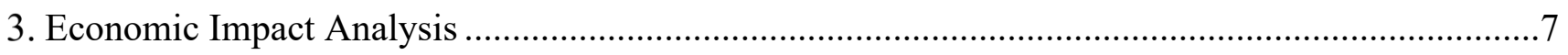

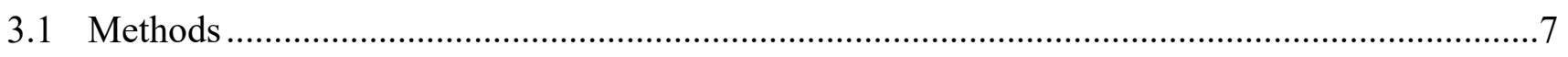

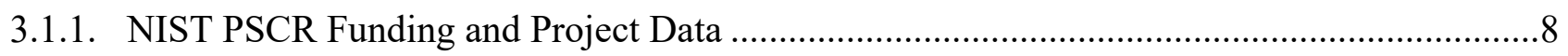

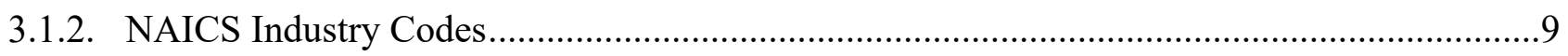

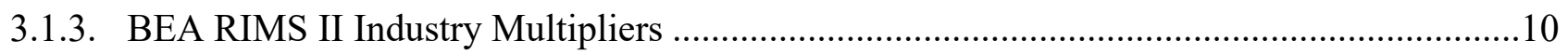

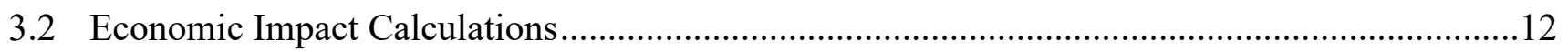

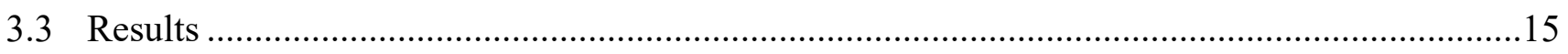

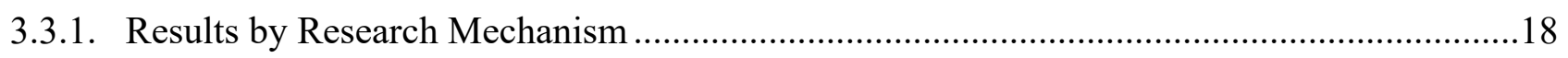

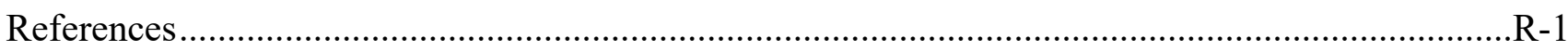

\section{List of Tables}

Table ES-1. Estimated Economic Impacts by Award.*................................................................. ES-3

Table ES-2. Impact by NIST PSCR Portfolio (Based on Multipliers). * ......................................... ES-4

Table ES-3. Economic Impacts by State Across Research Mechanisms........................................... ES-5

Table 1. Example Showing Primary and Secondary NAICS Assignments and Corresponding

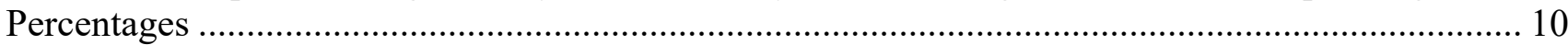

Table 2. Count of NIST PSCR Projects by RIMS II Industry Codes ................................................. 11

Table 3. Total Economic Impact by Research Mechanism (Based on Multipliers) ............................. 15

Table 4. Impact by NIST PSCR Portfolio (Based on Multipliers). * ……………………………..... 17

Table 5. Economic Impacts by State Across Research Mechanisms................................................... 17

Table 6. Economic Impacts Generated by Grants by Portfolio. …………………………................... 18

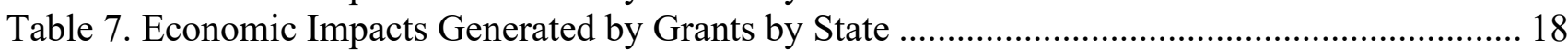

Table 8. Economic Impacts Generated by SIR Phase 3 Contract by Portfolio...................................... 19

Table 9. Economic Impacts Generated by SBIR Phase 3 Contract by State ....................................... 19

Table 10. Economic Impacts Generated by Prize Challenge Competitions by Portfolio ...................... 20

Table 11. Economic Impacts Generated by Prize Challenge Competitions by State ............................ 20

Table 12. Economic Impacts Generated by Internal NIST PSCR Research by Portfolio ..................... 21

Table 13. Economic Impacts Generated by Internal NIST PSCR Research by State .......................... 21 


\section{List of Figures}

Fig. 1. Count of Grant Awardees by NIST PSCR Portfolio....................................................... 3

Fig. 2. Count of Prize Challenges by Portfolio................................................................................. 6

Fig. 3. Count of Internal Research Project by Portfolio ............................................................... 7

Fig. 4. Simplified Economic Impact Calculation Tool Used for Grants, SBIR,and Internal Research14

Fig. 5. Simplified Economic Impact Calculation Tool Used for Prize Challenge Competitions. ....... 14

Fig. 6. Example of Calculation with Primary RIMS Multiplier. ................................................. 14

Fig. 7. NIST PSCR Investment in Research Generates Economic Impacts. ................................. 16 


\section{Executive Summary}

In February 2012, Congress' enactment of the Middle Class Tax Relief and Job Creation Act marked an unparalleled push toward next-generation technologies for public safety. The legislation contained landmark provisions for the development and build out of the Nationwide Public Safety Broadband Network (NPSBN), a dedicated, interoperable network for emergency responders. The Public Safety Trust Fund (PSTF) was established to support the design and implementation of the Network. The Act charged the National Institute of Standards and Technology (NIST) with utilizing up to \$300 million of PSTF allocations to establish an R\&D program to support the development and deployment of NPSBN between fiscal years 2016, when funds first became available, through 2022.

NIST's Public Safety Communications Research (PSCR) Division serves a primary role in fulfilling this Congressional mandate by advancing near- and long-term R\&D activities and ensuring that capabilities developed deliver positive operational impacts to responders in the field. NIST PSCR is the primary federal laboratory focused on conducting research, development, testing, and evaluation for public safety communications technologies. Their mission is to accelerate communications innovation in support of public safety communities and the citizens they serve.

In response to the Act's mandate, NIST PSCR developed the Public Safety Innovation Accelerator Program (PSIAP) in 2016. The program augments internal research by providing funds to support range of research mechanisms that span from external grants and cooperative research agreements to prize challenge competitions that focus on creative solutions. These research mechanisms are housed within six research portfolios and crosscutting initiatives to maximize their impact: ${ }^{1}$

- User Interface/User Experience (UI/UX),

- Location-Based Services (LBS),

- Mission Critical Voice (MCV),

- Public Safety Analytics,

- Security, and

- Resilient Systems.

The range of program partners and award recipients across portfolios includes academia, government, industry, and public safety entities. These partners and award recipients collaborate in an effort to foster creative solutions and technological advancements from multiple stakeholder perspectives to benefit the public safety community.

NIST PSCR recently completed an impact report ${ }^{2}$ of the work conducted under the first three years of the program (2017-2019) and is interested in further understanding how their investment in the research mechanisms central to the program result in economic impacts that span to the broader, regional economy. For purposes of this study, expenditures are categorized into four research mechanisms:

- Grants awarded to applicants through topic-specific funding opportunities as well as rolling grants focused on particular NIST PSCR portfolio objectives.

- Small Business Innovation Research (SBIR) Program Phase 3 Contracts between NIST PSCR and small businesses to help foster the development of products and solutions that align with NIST PSCR's mission.

\footnotetext{
${ }^{1}$ For purpose of economic impact calculations, "Open Innovation Team" and "Support \& Miscellaneous" were treated as portfolios in the analysis.

"Support \& Miscellaneous" is comprised of miscellaneous projects as well as all projects related to supporting internal research.

${ }^{2}$ https://www.nist.gov/publications/public-safety-communications-research-division-impact-report-fiscal-years-2017-150-2019 
- Prize challenge competitions where participants compete against one another to solve discrete and well-defined challenges that are common in public safety communications. NIST PSCR provides financial awards to the prize challenge "winners."

- Internal research that consists of a combination of: 1) research projects conducted by NIST PSCR staff on its Colorado and Maryland campuses to support specific research portfolios, 2) management and operational support for the research portfolios and administrative support for external funding mechanisms and 3) payable interagency agreements to support research projects.

These research mechanisms are central to NIST PSCR efforts to support the development and deployment of NPSBN and, ultimately, their mission is to accelerate communications innovation in support of public safety communities and the citizens they serve.

NIST PSCR contracted with Eastern Research Group, Inc. (ERG) of Lexington, MA to conduct an economic impact analysis (EIA) of PSTF investments into NIST PSCR's research mechanisms. This analysis demonstrates how the economic activity created through NIST PSCR's research mechanisms results in other spending and job support in the regional economy. More specifically, ERG conducted an EIA using standard economic input-output multipliers from the Bureau of Economic Analysis (BEA) to show how NIST PSCR's research investments translate into broader impacts to states, focusing on new jobs, earnings, value added, and total economic output. The findings will help NIST PSCR better understand how its investments in the different types of research mechanisms translate into economic impacts as it prepares for the remaining years of PSTF program funding.

ERG developed an Economic Impact Calculation tool to conduct the analysis. The Microsoft Excelbased tool captures and combines NIST PSCR project investment data with the BEA Regional InputOutput Modeling System (RIMS II) detailed industry code multipliers to estimate state-level economic impacts. The tool provides economic impact summary tables that show economic impacts generated by each NIST PSCR research mechanism and portfolio that can further parsed by state. ${ }^{3}$ The tool was designed for ongoing use by NIST PSCR, with user-friendly data input tabs, calculations and summary tables that auto-update, and accompanying user instructions.

To assess the economic impact of the NIST PSCR research mechanisms under this project, we performed three main tasks:

- We collected and compiled existing NIST PSCR data specific to each research mechanism on total dollars invested by NIST PSCR (e.g., total project dollars, total dollars awarded). This included 65 grants, 2 SBIR contracts, 170 prize challenge winners, and 170 funded internal research initiatives, comprised of 67 unique projects; a total of 407, or 304 unique, award and research projects, including 9 international awards

- We assessed the focus of each grant, SBIR contract, prize challenge, and internal research project (hereafter referred to collectively as "projects") and assigned an industry sector to each as defined by the Bureau of Economic Analysis (BEA) to facilitate economic impact modeling.

- We estimated economic impacts by combining the investment data we collected from NIST PSCR with BEA RIMS II (input-output) regional economic impact multipliers.

${ }^{3}$ https://www.bea.gov/resources/methodologies/RIMSII-user-guide 


\section{RESULTS \\ NIST PSCR research mechanisms generated \$509 million in total economic activity and 4,280 jobs.}

Table ES-1 summarizes the estimated economic impacts across the four categories of NIST PSCR research mechanisms considered in-scope for the analysis. ERG estimated these values by collecting data on project costs (i.e., NIST PSCR investment) and then applied appropriate state-level multipliers obtained from the BEA to each project. The first row of the table reports the values provided to ERG from PSCR's investments in its research portfolios. We convert those values to 2020 dollars in the second row to ensure all dollar amounts reflect comparable data. The final four rows of the table present the estimated economic impacts based on applying BEA RIMS multipliers. These estimates are described below.

Table ES-1. Estimated Economic Impacts by Award.*

\begin{tabular}{|c|c|c|c|c|c|}
\hline Category & Grants & SBIR & $\begin{array}{c}\text { Prize } \\
\text { Challenges }\end{array}$ & $\begin{array}{l}\text { Internal } \\
\text { Research }\end{array}$ & Total \\
\hline \multicolumn{6}{|l|}{ NIST Investments } \\
\hline Amount Invested (\$FY M) [a] & $\$ 73.94$ & $\$ 4.48$ & $\$ 3.50$ & $\$ 142.67$ & $\$ 224.59$ \\
\hline Amount Invested (\$2020 M) [b] & $\$ 68.07$ & $\$ 4.48$ & $\$ 3.44$ & $\$ 145.71$ & $\$ 221.71$ \\
\hline \multicolumn{6}{|l|}{ Estimated Economic Impacts } \\
\hline Total Output (\$2020 M) & $\$ 139.49$ & $\$ 9.13$ & $\$ 29.10$ & $\$ 332.12$ & $\$ 509.84$ \\
\hline Value-Added (\$2020 M) & $\$ 211.22$ & $\$ 5.88$ & $\$ 18.28$ & $\$ 195.81$ & $\$ 431.19$ \\
\hline Earnings (\$2020 M) & $\$ 123.36$ & $\$ 3.42$ & $\$ 10.65$ & $\$ 124.35$ & $\$ 261.78$ \\
\hline Jobs & 1,967 & 53 & 169 & 2,091 & 4,280 \\
\hline
\end{tabular}

${ }^{a}$ This sum reflects dollars invested by NIST PSCR for the original fiscal year of the investment and sums across fiscal years FY16-FY20 rather than putting all dollars in the same fiscal year. This number includes 9 international awards.

${ }^{\mathrm{b}}$ This amount invested has been inflated to \$2020 and excludes 9 international awards, totaling \$7.98 M (\$2020). We only included projects with domestic multipliers in the economic impact analysis

*NIST PSCR investment in international-based research is included in the investment totals but is not represented in the reported economic impacts. BEA RIMS II multipliers are state-specific and do not account for international entities.

Overall, NIST PSCR invested \$224.6 million in its research portfolios from 2016 to 2020. When converted to 2020 dollars, this amounted to a total investment of \$229.7 million. Then, for this analysis, we removed 9 international awards, totaling \$7.98 million, leaving \$221.7 million. Using this value as a starting point, we applied BEA RIMS multipliers to the investment value. There are four categories of multipliers we looked at:

- Output multipliers reflect the change in the output of industries in a region for a one-dollar change in demand for a specific industry. That is, what is the total value of economic activity circulating through the states' economies generated by PSCR's R\&D investments? We found that the combined total output across research mechanisms, is just over \$509 million.

- Value-added multipliers reflect the change in regional value-added (gross domestic product, GDP) for a one-dollar change in demand for a specific industry. That is, value-added indicates how much the regional economies grew over a period of time due to PSCR's R\&D investments. Our estimates indicate that the NIST PSCR research mechanisms resulted in an increase of just over \$431 million in value-added, across all states with entities participating in the four NIST PSCR research mechanisms.

- Earnings multipliers reflect the total change in household earnings in the region for a one-dollar change in demand for a specific industry. That is, what is the change in household earnings in the 
states' economies generated by PSCR's R\&D investments? NIST PSCR research mechanisms led to an increase of approximately \$262 million in earnings.

- Jobs multipliers reflect the change in the total number of jobs (full- and part-time) per a onemillion-dollar change in the demand for a specific industry. That is, what is the change in the number of full- and part-time jobs generated by each one-million-dollar change in the states' economic activity due to PSCR's R\&D investments? NIST PSCR research mechanisms led to 4,280 new jobs.

Table ES-2 provides a breakdown of NIST PSCR investment and the resulting economic impacts across the six NIST PSCR research portfolios, Open Innovation Team projects, and all internal projects classified as Support and Miscellaneous. When comparing the NIST PSCR investment to economic impacts generated by that investment, the four portfolios that generated the largest economic output per dollar invested were Resilient Systems (\$2.6 per \$1 invested), Security (\$2.5 per \$1 invested), and UI/UX and Open Innovation Team (both with $\$ 2.4$ per $\$ 1$ invested). ${ }^{4}$

Table ES-2. Impact by NIST PSCR Portfolio (Based on Multipliers).*

\begin{tabular}{|c|c|c|c|c|c|c|}
\hline & $\begin{array}{c}\text { Number } \\
\text { of } \\
\text { Projects } \\
\text { [a] } \\
\end{array}$ & $\begin{array}{c}\text { NIST } \\
\text { PSCR } \\
\text { Investmen } \\
\mathbf{t}(\$ 2020 \\
\text { M) } \\
\end{array}$ & $\begin{array}{c}\text { Output } \\
(\$ 2020 \mathrm{M})\end{array}$ & $\begin{array}{c}\text { Value- } \\
\text { Added } \\
\text { (\$2020 M) }\end{array}$ & $\begin{array}{l}\text { Earnings } \\
(\$ 2020 \mathrm{M})\end{array}$ & Jobs \\
\hline Data Analytics & 63 & $\$ 16.35$ & $\$ 37.50$ & $\$ 48.72$ & $\$ 27.10$ & 450 \\
\hline Location Based Services & 42 & $\$ 21.36$ & $\$ 45.15$ & $\$ 39.32$ & $\$ 22.86$ & 364 \\
\hline Mission Critical Voice & 62 & $\$ 36.06$ & $\$ 76.35$ & $\$ 80.78$ & $\$ 47.45$ & 740 \\
\hline Resilient Systems & 55 & $\$ 9.28$ & $\$ 24.45$ & $\$ 39.31$ & $\$ 23.50$ & 361 \\
\hline Security & 47 & $\$ 8.18$ & $\$ 20.26$ & $\$ 12.06$ & $\$ 7.22$ & 117 \\
\hline $\mathrm{UI} / \mathrm{UX}$ & 101 & $\$ 22.76$ & $\$ 54.96$ & $\$ 64.11$ & $\$ 38.99$ & 626 \\
\hline $\begin{array}{l}\text { Support \& Misc. Projects } \\
\text { [b] }\end{array}$ & 20 & $\$ 94.09$ & $\$ 218.10$ & $\$ 127.42$ & $\$ 81.54$ & 1,393 \\
\hline Open Innovation Team & 10 & $\$ 13.62$ & $\$ 33.09$ & $\$ 19.47$ & $\$ 13.13$ & 228 \\
\hline Total & 398 & $\$ 221.7$ & $\$ 509.8$ & $\$ 431.2$ & $\$ 261.8$ & 4,280 \\
\hline
\end{tabular}

*In some instances, NIST PSCR Prize challenges were associated with all PSCR portfolios rather than a single portfolio. In these instances, the NIST PSCR investment for the project is divided evenly across each of the portfolios in order to evenly distribute the economic impacts of those investments.

${ }^{a}$ This excludes 9 international projects since they are not included in the analysis. Total projects including international projects is 407 .

${ }^{\mathrm{b}}$ These do not include Open Innovation Team funding and outputs.

Table ES-3 shows the economic impacts by state across all research mechanisms. States with the greatest number of projects include Colorado (CO), Maryland (MD), California, and Texas. NIST PSCR's internal research work is responsible for the high number of projects in $\mathrm{CO}$ and $\mathrm{MD}$, as this research takes place at NIST campuses in both states.

\footnotetext{
${ }^{4}$ The difference in economic impact generated by each portfolio is due to the fact that each portfolio contains a mixture of different project-types associated with different industry sectors, and the work activities conducted for each portfolio occur in different geographies. This means that the PSCR dollars invested in each portfolio filter through economic impact multipliers that are both state- and sector-specific. Thus, the multipliers applied to each portfolio differ, and the application of these differing multipliers result in varying economic impacts for a \$1 PSCR investment in a given portfolio.
} 
Table ES-3. Economic Impacts by State Across Research Mechanisms.

\begin{tabular}{|c|c|c|c|c|c|c|}
\hline State & $\begin{array}{l}\text { NIST PSCR } \\
\text { Investment } \\
(\$ 2020 \mathrm{M}) \\
\end{array}$ & $\begin{array}{l}\text { Number of } \\
\text { Projects }\end{array}$ & $\begin{array}{c}\text { Output } \\
(\$ 2020 \mathrm{M})\end{array}$ & $\begin{array}{c}\text { Value-Added } \\
(\$ 2020 \mathrm{M})\end{array}$ & $\begin{array}{l}\text { Earnings } \\
(\$ 2020 \mathrm{M})\end{array}$ & Jobs \\
\hline $\mathrm{AR}$ & $\$ 0.00$ & 1 & $\$ 0.13$ & $\$ 0.09$ & $\$ 0.06$ & 1 \\
\hline $\mathrm{CA}$ & $\$ 8.30$ & 48 & $\$ 24.22$ & $\$ 28.70$ & $\$ 17.47$ & 250 \\
\hline $\mathrm{CO}$ & $\$ 131.06$ & 110 & $\$ 304.25$ & $\$ 183.34$ & $\$ 117.40$ & 1984 \\
\hline $\mathrm{CT}$ & $\$ 0.14$ & 1 & $\$ 0.26$ & $\$ 0.47$ & $\$ 0.22$ & 4 \\
\hline $\mathrm{DC}$ & $\$ 1.34$ & 3 & $\$ 1.90$ & $\$ 1.08$ & $\$ 0.22$ & 3 \\
\hline $\mathrm{FL}$ & $\$ 0.86$ & 12 & $\$ 3.02$ & $\$ 3.94$ & $\$ 2.45$ & 44 \\
\hline GA & $\$ 5.89$ & 10 & $\$ 14.38$ & $\$ 21.26$ & $\$ 12.70$ & 230 \\
\hline IL & $\$ 0.04$ & 4 & $\$ 1.42$ & $\$ 0.93$ & $\$ 0.57$ & 8 \\
\hline IN & $\$ 8.36$ & 13 & $\$ 17.43$ & $\$ 9.91$ & $\$ 5.96$ & 93 \\
\hline IA & $\$ 0.01$ & 1 & $\$ 0.10$ & $\$ 0.06$ & $\$ 0.04$ & 1 \\
\hline $\mathrm{KS}$ & $\$ 0.09$ & 2 & $\$ 0.46$ & $\$ 0.24$ & $\$ 0.11$ & 2 \\
\hline KY & $\$ 0.02$ & 1 & $\$ 0.22$ & $\$ 0.11$ & $\$ 0.05$ & 1 \\
\hline MD & $\$ 17.25$ & 80 & $\$ 34.57$ & $\$ 24.18$ & $\$ 13.37$ & 205 \\
\hline MA & $\$ 2.87$ & 6 & $\$ 6.00$ & $\$ 7.74$ & $\$ 4.56$ & 64 \\
\hline MI & $\$ 4.57$ & 7 & $\$ 9.20$ & $\$ 14.28$ & $\$ 8.76$ & 148 \\
\hline $\mathrm{MN}$ & $\$ 0.00$ & 1 & $\$ 0.06$ & $\$ 0.03$ & $\$ 0.01$ & 0 \\
\hline MS & $\$ 0.18$ & 1 & $\$ 0.33$ & $\$ 0.80$ & $\$ 0.52$ & 10 \\
\hline MT & $\$ 0.02$ & 1 & $\$ 0.19$ & $\$ 0.09$ & $\$ 0.05$ & 1 \\
\hline $\mathrm{NJ}$ & $\$ 4.66$ & 7 & $\$ 10.48$ & $\$ 17.74$ & $\$ 9.93$ & 144 \\
\hline NY & $\$ 6.16$ & 9 & $\$ 12.12$ & $\$ 14.56$ & $\$ 7.91$ & 112 \\
\hline $\mathrm{NC}$ & $\$ 3.89$ & 14 & $\$ 9.11$ & $\$ 18.79$ & $\$ 11.62$ & 192 \\
\hline ND & $\$ 0.01$ & 1 & $\$ 0.05$ & $\$ 0.01$ & $\$ 0.01$ & 0 \\
\hline $\mathrm{OH}$ & $\$ 1.01$ & 6 & $\$ 2.60$ & $\$ 4.56$ & $\$ 2.48$ & 48 \\
\hline OK & $\$ 0.02$ & 1 & $\$ 0.13$ & $\$ 0.08$ & $\$ 0.05$ & 1 \\
\hline OR & $\$ 1.75$ & 1 & $\$ 3.30$ & $\$ 4.22$ & $\$ 2.31$ & 40 \\
\hline PA & $\$ 4.80$ & 11 & $\$ 10.21$ & $\$ 15.03$ & $\$ 8.97$ & 139 \\
\hline $\mathrm{TN}$ & $\$ 0.46$ & 1 & $\$ 0.99$ & $\$ 2.11$ & $\$ 1.02$ & 19 \\
\hline $\mathrm{TX}$ & $\$ 9.81$ & 23 & $\$ 24.75$ & $\$ 38.17$ & $\$ 22.33$ & 375 \\
\hline VA & $\$ 6.52$ & 14 & $\$ 13.85$ & $\$ 15.00$ & $\$ 8.37$ & 128 \\
\hline WA & $\$ 1.62$ & 8 & $\$ 4.13$ & $\$ 3.67$ & $\$ 2.28$ & 32 \\
\hline
\end{tabular}




\section{Introduction}

In February 2012, Congress' enactment of the Middle Class Tax Relief and Job Creation Act marked an unparalleled push toward next-generation technologies for public safety. The legislation contained landmark provisions for the development and build out of the Nationwide Public Safety Broadband Network (NPSBN), a dedicated, interoperable network for emergency responders. The Public Safety Trust Fund (PSTF) was established to support the design and implementation of the Network. The Act charged the National Institute of Standards and Technology (NIST) with utilizing up to \$300 million of PSTF allocations to establish an R\&D program to support the development and deployment of NPSBN between fiscal years 2016, when funds first became available, through 2022.

NIST's Public Safety Communications Research (PSCR) Division serves a primary role in fulfilling this Congressional mandate by advancing near- and long-term R\&D activities and ensuring that capabilities developed deliver positive operational impacts to responders in the field. NIST PSCR is the primary federal laboratory focused on conducting research, development, testing, and evaluation for public safety communications technologies. Their mission is to accelerate communications innovation in support of public safety communities and the citizens they serve.

In response to the Act's mandate, NIST PSCR developed the Public Safety Innovation Accelerator Program (PSIAP) in 2016. The program augments internal research by providing funds to support range of research mechanisms that span from external grants and cooperative research agreements to prize challenge competitions that focus on creative solutions. These research mechanisms are housed within six research portfolios and crosscutting initiatives to maximize their impact: ${ }^{5}$

- User Interface/User Experience (UI/UX),

- Location-Based Services (LBS),

- Mission Critical Voice (MCV),

- Public Safety Analytics,

- Security, and

- Resilient Systems.

The range of program partners and award recipients across portfolios includes academia, government, industry, and public safety entities. These partners and award recipients collaborate in an effort to foster creative solutions and technological advancements from multiple stakeholder perspectives to benefit the public safety community.

NIST PSCR recently completed an impact report ${ }^{6}$ of the work conducted under the first three years of the program (2017-2019) and is interested in further understanding how their investment in the research mechanisms central to the program result in economic impacts that span to the broader, regional economy. For purposes of this study, expenditures are categorized into four research mechanisms:

- Grants awarded to applicants through topic-specific funding opportunities as well as rolling grants focused on particular NIST PSCR portfolio objectives.

- Small Business Innovation Research (SBIR) Program Phase 3 Contracts between NIST PSCR and small businesses to help foster the development of products and solutions that align with NIST PSCR's mission.

\footnotetext{
${ }^{5}$ For purpose of economic impact calculations, "Open Innovation Team" and "Support \& Miscellaneous" were treated as portfolios in the analysis. "Support \& Miscellaneous" is comprised of miscellaneous projects as well as all projects related to supporting internal research.

${ }^{6}$ https://www.nist.gov/publications/public-safety-communications-research-division-impact-report-fiscal-years-2017-150-2019
} 
- Prize challenge competitions where participants compete against one another to solve discrete and well-defined challenges that are common in public safety communications. NIST PSCR provides financial awards to the prize challenge "winners."

- Internal research that consists of a combination of: 1) research projects conducted by NIST PSCR staff on its Colorado and Maryland campuses to support specific research portfolios, 2) management and operational support for the research portfolios and administrative support for external funding mechanisms and 3) payable interagency agreements to support research projects.

These research mechanisms are central to NIST PSCR efforts to support the development and deployment of NPSBN and, ultimately, their mission is to accelerate communications innovation in support of public safety communities and the citizens they serve.

NIST PSCR contracted with Eastern Research Group, Inc. (ERG) of Lexington, MA to conduct an economic impact analysis (EIA) of PSTF investments into NIST PSCR's research mechanisms. This analysis demonstrates how the economic activity created through NIST PSCR's research mechanisms results in other spending and job support in the regional economy. More specifically, ERG conducted an EIA using standard economic input-output multipliers from the Bureau of Economic Analysis (BEA) to show how NIST PSCR's research investments translate into broader impacts to states, focusing on new jobs, earnings, value added, and total economic output. The findings will help NIST PSCR better understand how its investments in the different types of research mechanisms translate into economic impacts as it prepares for the remaining years of PSTF program funding.

ERG developed an Economic Impact Calculation tool to conduct the analysis. The Microsoft Excelbased tool captures and combines NIST PSCR project investment data with the BEA Regional InputOutput Modeling System (RIMS II) detailed industry code multipliers to estimate state-level economic impacts. The tool provides economic impact summary tables that show economic impacts generated by each NIST PSCR research mechanism and portfolio that can further parsed by state. ${ }^{7}$ The tool was designed for ongoing use by NIST PSCR, with user-friendly data input tabs, calculations and summary tables that auto-update, and accompanying user instructions.

\subsection{Report Overview}

The remainder of this report is laid out as follows: Section 2 provides a characterization of the participants involved in each the four NIST PSCR research mechanisms included in the economic impact analysis.

Section 3 describes the methods used to calculate the economic impacts of the NIST PSCR research mechanisms based on the NIST PSCR data we collected and using impact multipliers obtained from the Bureau of Economic Analysis (BEA) along with results of the analysis.

\section{Characterizing Research Mechanisms}

This section provides a detailed characterization of each PSCR research mechanism and their participants.

${ }^{7}$ https://www.bea.gov/resources/methodologies/RIMSII-user-guide 


\subsection{Grants}

Thirteen NIST PSCR grant opportunities are represented in the data used in the analysis. These topic-specific grant opportunities include (organized by grant award date):

- PSIAP 2017 (Awarded: 2017), aimed at advancing broadband communications technologies for first responders by supporting the migration of data, video and voice communications from mobile radio to a nationwide public safety broadband network, as well as accelerating critical technologies related to indoor location tracking and public safety analytics. ${ }^{8}$

- PSIAP Point Cloud City (Awarded: 2018), focused on generating an extensive catalog of annotated 3D indoor point clouds that can be used by industry, academia, and government to advance research and development in areas of interest, such as indoor mapping, localization and navigation for public safety. This grant opportunity also aims to demonstrate the potential value of ubiquitous indoor positioning and location-based information. ${ }^{9}$

- PSIAP User Interface (Awarded: 2018), aimed to create new or apply current technology that will enable researchers to better assess public safety user interfaces using virtual reality (VR) and augmented reality (AR). ${ }^{10}$

- PSIAP i-Axis (Awarded: 2019), sought to conduct interactive workshops, summits, exercises, and training to produce technical outputs (i.e., standard operating procedures, best practices guides, implementation templates, etc.), which will be made available to the entire public safety stakeholder community. ${ }^{11}$

- PSIAP Mission Critical Voice Test Equipment (Awarded: 2019), aimed to support research and development around the creation of a simulator program enabling necessary testing of Mission Critical Services (MCS) technology, such as Mission Critical Push To Talk (MCPTT), Mission Critical Video (MCVideo), and Mission Critical Data (MCData). ${ }^{12}$

- PSIAP Mission Critical Voice Quality of Experience (QoE) (Awarded: 2019), intended to generate publicly-released data sets and a QoE model correlating impairments in communication systems used by first responders and real task performance by creating test devices to simulate current impairments, developing a test methodology for human testing, and applying these tests to a diverse pool of first responders. ${ }^{13}$

- PSIAP Augmented Reality (Awarded: 2021), aimed to implement technology that will enable researchers to test and develop user interfaces to enhance public safety by creating new technology or applying current technology to a specific public safety use case. ${ }^{14}$

\footnotetext{
${ }^{8}$ https://www.nist.gov/ctl/pscr/funding-opportunities/past-funding-opportunities/psiap-2017

9 https://www.nist.gov/ctl/pscr/funding-opportunities/past-funding-opportunities/psiap-point-cloud-city

${ }^{10}$ https://www.nist.gov/ctl/pscr/funding-opportunities/past-funding-opportunities/psiap-user-interface

${ }_{11}^{11}$ https://www.nist.gov/ctl/pscr/funding-opportunities/past-funding-opportunities/psiap-i-axis

${ }^{12}$ https://www.nist.gov/ctl/pscr/funding-opportunities/past-funding-opportunities/psiap-mcv-test-equipment

${ }_{13}^{13}$ https://www.nist.gov/ctl/pscr/funding-opportunities/past-funding-opportunities/psiap-mcv-qoe

${ }^{14}$ https://www.nist.gov/ctl/pscr/psiap-augmented-reality
} 
- PSIAP FR3D (Awarded: 2021), aimed to achieve major upgrades in the performance of sensors and systems for localization and tracking of first responders operating indoors in a variety of building environments without any benefit of pre-deployed dedicated infrastructure. ${ }^{15}$

- PSIAP 2020 Technical and Business Assistance (TABA) and Demonstration (Awarded: 2021), intended to more rapidly advance public-safety focused communication technology prototypes through needed technical and business assistance or develop a demonstration project with a partnering public safety agency to provide additional testing and research. ${ }^{16}$

- Measurement, Science and Engineering (MSE) Rolling Grants (ongoing awards), with grants from Analytics, Mission Critical Voice, Systems Security and User Interface/User Experience Portfolios.

Across these grant opportunities, NIST PSCR funding was distributed via 65 awards to 56 unique entities, 5 of which were international. Figure 1 shows how the 65 grant awards were distributed across the six NIST PSCR research portfolios, with MCV (16), UI/UX (15), and LBS (14) associated with the greatest number of in-scope awards. Geographically, grant awardees were located in 21 states and 3 countries, with the most awardees located in the following states: Texas (6), Michigan (6), California (5), North Carolina (5), and Pennsylvania (5).

\subsection{SBIR Phase 3 Contracts}

There were two SBIR contracts considered for this analysis. Geographically, one business is located in Texas, while the other is located in Virginia. Each collaborator's work is focused on a different NIST research portfolio, MCV and UI/UX corresponding, with the research underway.

\subsection{Prize Challenges}

There were sixteen prize challenge competitions considered for this analysis:

- The Future of Public Safety Technology 100k Video Series (Commenced: 2017), a challenge to create a series of videos, with corresponding social cut-downs, that will explain Open Innovation and NIST's PSCR Open Innovation Accelerator to the public, while covering each of the key public safety technology programs that are a part of it. ${ }^{17}$

- Virtual Public Safety Test Environment Challenge (Commenced: 2017), a challenge focused on "measurement environments that use immersive virtual reality tools in conjunction with physical spaces to simulate first responder scenarios for accurate and repeatable testing of new first responder interfaces and technologies."18

- Differential Privacy Synthetic Data Challenge (DEiD 1.0) (Commenced 2018), "tasked participants with creating new methods, or improving existing methods of data de-identification, while preserving the dataset's utility for analysis." 19

- First Responder Virtual Reality Heads-up Display Navigation Challenge (VR Heads-Up) (Commenced: 2018), created "a heads-up display (HUD) for navigation with unimpeded visual aids," supporting first responders and helping PSCR advance research for user interface (UI) technology. ${ }^{20}$

\footnotetext{
${ }^{15}$ https://www.nist.gov/ctl/pscr/psiap-first-responder-3d-indoor-tracking

${ }^{16}$ https://www.nist.gov/ctl/pscr/commercialization/psiap-taba-demonstration

${ }^{17}$ https://tongal.com/project/TheFutureofPublicSafetyTechnology/\#tab-brief

${ }^{18}$ https://www.nist.gov/ctl/pscr/open-innovation-prize-challenges/past-prize-challenges/2017-virtual-public-safety-test

${ }^{19} \mathrm{https} / /$ www.nist.gov/ctl/pscr/open-innovation-prize-challenges/past-prize-challenges/2018-differential-privacy-synthetic

${ }^{20}$ https://www.nist.gov/ctl/pscr/open-innovation-prize-challenges/past-prize-challenges/2018-virtual-reality-heads-display
} 
- The Unlinkable Data Challenge (Commenced: 2018), a challenge to propose and implement a mechanism to enable the protection of personally identifiable information while maintaining a dataset's utility for analysis. $^{21}$

- Unmanned Aerial Systems Flight and Payload Challenge (UAS 1.0) (Commenced: 2018), a challenge to "help public safety operations by keeping a UAS and its payload airborne for the longest time possible with vertical and hovering accuracy."22

- Expanding the SIM Card Use for Public Safety (SIM Card) (Commenced: 2019), raised "awareness of the need for convenient, standards-based, two-factor authentication for emergency responders, while demonstrating an innovative approach to authentication that could lead to future innovations." 23

- Haptic Interfaces for Public Safety Challenge (Haptics) (Commenced: 2019), a challenge focused on how haptic interfaces can assist first responders in both VR and real-world scenarios. Haptic interface prototypes were evaluated on how they "impact a first responder's performance in three virtual reality (VR) scenarios [law enforcement, emergency medical services (EMS), and fire service], and how, once embedded into firefighter personal protective equipment (PPE), the prototypes assist firefighters in a realistic scenario as they navigate and conduct a search and rescue task at a firefighter training facility." 24

- Tech to Protect (Commenced: 2019), "designed to engage entrepreneurs, technologists, students, programmers, designers and public safety experts to create solutions across critical technical areas of public safety communications, including secure communications, locationbased services, public safety data analytics, mission-critical voice and user interface/user experience (UI/UX).” Proposed solutions support emergency responders' use of advanced communications technologies in their day-to-day activities. ${ }^{25}$

- Automated Streams Analysis for Public Safety (ASAPS) (Commenced: 2020), an “(Artificial Intelligence) challenge to detect, analyze, and alert public safety to emergencies from streaming data. The vision of this challenge is to stimulate pioneering research that will provide public safety with advanced real-time emergency detection, situational awareness, and decision-making capabilities from many live unstructured data streams." 26

- CHARIoT Challenge (Commenced: 2020), a two-pronged multi-phase competition "to develop solutions that can identify and transmit scenario-accurate city and personal network data streams or deliver first responders actionable and intuitive augmented reality interfaces." 27

- Differential Privacy Temporal Map Data Challenge (DEiD 2.0) (Commenced: 2020), extended the reach and utility of differential privacy algorithms through the development of temporal map data, utility metrics, de-identification algorithms, and open-source development of resulting software. ${ }^{28}$

\footnotetext{
${ }^{21}$ https://www.nist.gov/ctl/pscr/open-innovation-prize-challenges/past-prize-challenges/2018-unlinkable-data-challenge

${ }^{22}$ https://www.nist.gov/ctl/pscr/open-innovation-prize-challenges/past-prize-challenges/2018-unmanned-aerial-systems-flight

${ }_{23}^{23}$ https://www.nist.gov/ctl/pscr/open-innovation-prize-challenges/past-prize-challenges/2019-expanding-sim-card-use-public

${ }^{24}$ https://www.nist.gov/ctl/pscr/open-innovation-prize-challenges/past-prize-challenges/2019-haptic-interfaces-public-safety

${ }^{25}$ https://www.nist.gov/ctl/pscr/open-innovation-prize-challenges/past-prize-challenges/2019-tech-protect-challenge

${ }^{26}$ https://www.asapschallenge.ai/

${ }^{27} \mathrm{https://www.nist.gov/ctl/pscr/open-innovation-prize-challenges/current-and-upcoming-prize-challenges/2020-chariot}$

${ }^{28}$ https://www.nist.gov/ct//pscr/open-innovation-prize-challenges/current-and-upcoming-prize-challenges/2020-differential
} 
- Enhancing Computer Vision for Public Safety Challenge (Commenced: 2020), "focused on advancing the capacity of no-reference (NR) metrics and computer vision algorithms to support public safety missions." Applicants created "image or video datasets that depict camera capture problems, such as grime on the lens or sun flare, that cause issues for computer vision applications." 29

\section{- First Responder UAS Endurance} Challenge (UAS 2.0) (Commenced: 2020), aimed to create and build a powerful drone intended to support first responders on critical, life-saving missions by expanding drones' capabilities (i.e., vertical takeoff and landing, accuracy, stability, safety), payload management, and flight endurance). ${ }^{30}$

Figure 2 shows how these prize challenges correspond with the NIST PSCR research portfolios. As the figure indicates, the greatest number prize challenge competitions were associated with the UI/UX (5) and Data Analytics (4) portfolios. ${ }^{31}$

Across these challenges, there were 170 total winners (including those that received no cash prizes and 4 international awards), and 152 unique winners. Geographically, challenge winners were located in twenty-six states and four countries, with the majority of winners located in: California (43), Texas (12), and Indiana (11)).

\subsection{Internal Research}

Internal research is conducted by NIST PSCR staff on its Colorado and Maryland campuses to support specific research needs as well as the management and project support for a range of research mechanisms across NIST PSCR portfolios.

\footnotetext{
${ }^{29} \mathrm{https}$ ://www.nist.gov/ctl/pscr/open-innovation-prize-challenges/current-and-upcoming-prize-challenges/2020-enhancing

${ }^{30}$ https://www.firstresponderuaschallenge.org/index.php\#about

${ }_{31}$ Two prize challenges were identified as contributing to all NIST portfolios in the data and are counted separately, as they do not represent an additional, unique prize challenge for each portfolio.
} 
Figure 3 shows the count of internal research initiatives by PSCR portfolio. As the figure indicates, the largest number of internal research projects correspond with the MCV (40) and Security (32) portfolios $^{32}$.

\section{Economic Impact Analysis}

This section describes the economic impact analysis (EIA) conducted by ERG that demonstrates how the economic activity created through NIST PSCR's research mechanisms results in broader impacts to states, focusing on the creation of new jobs, earnings, value added, and total economic output. The economic impacts are estimated by applying standard economic inputoutput multipliers to the NIST PSCR research investment dollars, which does not account for the ultimate value to public safety generated by the research and development (R\&D) conducted. Below, the methods used to conduct the analysis are presented, followed by the economic impact results.

\subsection{Methods}

Four key steps were used to conduct the economic impact analysis:

- First, we collected and compiled existing NIST PSCR data specific to each research mechanism on total dollars invested by NIST PSCR (e.g., total project dollars, total dollars awarded). Along the way, we converted the reported dollars to 2020 dollars to ensure the values were comparable with respect to inflation adjustments.

- Second, we assessed the focus of each research project, grant, SBIR Phase 3 contract, and prize challenge assigned an industry sector to each as defined by the North American Industry Classification System (NAICS). Assigning appropriate NAICS codes is key to performing EIA since the impact multipliers are specific to different industries.

- Third, we identified and obtained multipliers from the Bureau of Economic Analysis's (BEA's) Regional Input-Output Modeling System (RIMS II) model that we used to estimate how changes in demand, caused by NIST PSCR's investment, ripple through the economy of the states in which the activities occur.

- Finally, we calculated economic impacts by applying the state-specific BEA RIMS II multipliers to the NIST PSCR economic data. For prize challenges, an additional mark-up was applied to the NIST PSCR investment dollars prior to applying the state-specific multipliers in order to reflect that prize challenge winners likely spent more than the prize amount in resources to obtain the prize.

Each of these steps is described in additional detail below.

\footnotetext{
${ }^{32}$ These numbers count projects that span multiple years as separate initiatives for each year.
} 


\subsection{1. $\quad$ NIST PSCR Funding and Project Data}

NIST PSCR provided ERG with funding data at the internal research project, grant, SBIR contract, and prize challenge award levels. This data included information on total project or award dollars and/or data that could be used to establish these values (e.g., other object and labor costs). In addition to the funding data, NIST PSCR also provided a range of data across research mechanisms that could be used to determine industry information for use in the analysis, as described further in the section that follows. In some instances, we supplemented NIST PSCR data through a search of publicly available information to obtain key information needed to conduct the analysis. The funding and project data collected and compiled for each research mechanism is described further below.

\subsubsection{Grants and SBIR contracts}

NIST PSCR provided ERG with a Microsoft Excel spreadsheet containing PSCR-funded grants and SBIR contracts. The elements in the data contained:

- Funding amounts

- Year of award

- A brief description of the grant and SBIR work conducted

- Geographic location where grant and SBIR work occurred

- $\quad$ NIST PSCR research portfolio corresponding to each grant and SBIR

ERG supplemented NIST PSCR grant data by developing grant project descriptions from the program's "Past Funding Opportunities" webpage that could be used to determine relevant industry sectors when apply NAICS codes (See Sec. 3.1.2). ${ }^{33}$

\subsubsection{Prize Challenges}

NIST PSCR provided ERG with a Microsoft Excel spreadsheet containing:

- A list of prize challenge competitions and the associated winners of each

- Dollars awarded

- $\quad$ PSCR research portfolio corresponding to each grant

ERG performed additional research on each prize challenge competition to identify a description of the prize challenge, year that the competition occurred, and challenge-winning projects and/or solutions that could be used to identify relevant industry information for the analysis. Lastly, ERG conducted an internet search of academic literature to identify possible studies that could inform methods for estimating the economic impact resulting from prize challenge competitions that considers impacts spurred by the initial product or solution developed for the competition.

ERG identified a study by Cason et al (2017) who posit that prize challenge winners are likely to incur effort in excess of the prize amount. ${ }^{34}$ The study suggests that the effort expended potentially exceeds the prize amount by 45 percent. Thus, we applied a 45 percent mark-up based on the top

\footnotetext{
${ }^{33}$ https://www.nist.gov/ct//pscr/funding-opportunities/past-funding-opportunities

${ }_{34}^{34}$ Cason, T.N., Masters, W.A. and Sheremeta, R.M., 2018. Winner-take-all and proportional-prize contests: theory and experimental results. Journal of Economic Behavior \& Organization.
} 
prize amount to each awardee. ${ }^{35}$ This mark-up was applied in the economic impact calculation for prize challenges, as further described in Section 3.2.

\subsubsection{Internal Research}

NIST PSCR provided ERG with the following data via several Microsoft Excel spreadsheets:

- Internal research projects by fiscal year

- A brief description of the project or research conducted

- PSCR research portfolio corresponding to each project

- Project cost information comprised of:

- Total project costs (i.e., dollars invested by PSCR) where available

- Labor and other object cost data that could be used to determine total project costs, where total project cost data was not available.

- Overhead costs associated with internal research projects in the 'Support \& Miscellaneous Portfolio' by fiscal year

ERG then supplemented, integrated, and reformatted NIST PSCR internal research data so that it could be easily integrated into the tool.

- Supplemented Project Descriptions. ERG worked with NIST PSCR to supplement and better understand internal research project descriptions related to staff time, administration, lab operations, or management. For these projects, NIST PSCR further described whether the work was mainly managerial, administrative, or technical in nature to allow for industry code assignments (as described in the next section). For those projects that were identified as "technical" in nature, NIST PSCR further delineated the activities between early R\&D technical work (taking place mostly at a desk), and advanced technical R\&D work (taking place mostly in a lab).

- Allocated and Integrated Other Object Costs. NIST PSCR provided other object cost (OOC) data to be integrated with labor dollar values to calculate total project cost in instances where the total project costs were not already available. For Mission Critical Voice and Location-Based Services portfolios, the other object data was provided for a set of projects for a given fiscal year, along with a description of how the OOCs should be allocated across those projects. ERG reformatted each set of projects associated with an OOC so that the tool listed individual projects in each row by fiscal year. We then allocated the OCC costs across those projects as directed by NIST PSCR. The OOCs for each project were then summed with the labor costs for that project to calculate total project costs.

- Allocated and Integrate Overhead Costs. Overhead costs were provided for internal research projects from FY16-FY20. ERG divided the total overhead costs for each fiscal year equally among all projects in the "Support \& Miscellaneous" portfolio for that year. The resulting overhead cost was then added to the corresponding project costs.

\subsubsection{NAICS Industry Codes}

As a first step toward determining the appropriate industry multipliers for use in the analysis, we assigned a six-digit North American Industry Classification System (NAICS) code to each internal

\footnotetext{
${ }^{35}$ For example, if three awards were provided (i.e., first, second and third place) and the first-place award was $\$ 10,000$, we added $\$ 4,500$ to each award winner to reflect the amount of effort expended to obtain the award.
} 
research project, grant, SBIR contract, and prize challenge (hereafter referred to collectively as "projects"). We used the project descriptions included in the NIST PSCR data that indicate the type of work being conducted to identify corresponding industry descriptions. ${ }^{36}$ ERG conducted a preliminary assignment of NAICS codes across projects and then obtained feedback from NIST PSCR on the relevance and appropriateness of codes selected prior to finalizing the code assignments.

For many of the projects, the scope of activities could not be fully described by only one NAICS code, so in these cases we assigned up two NAICS codes for each project that we termed "primary" and "secondary" NAICS codes, where the "primary" code was associated either 50 percent or 75 percent of the total funding value. Our default was to assume the work could be split equally (50 percent) between the two codes. In cases where ERG and NIST PSCR agreed, we assigned one code 75 percent reflecting the idea that the work was more concentrated in one area over another. We did not attempt to estimate more fine-tuned value (i.e., values different than 50 and 75 percent for the primary NAICS) since we did not have the time or resources available to make those determinations for all the projects. Table 1 provides an example of assigning one code 75 percent of a project's work to a primary NAICS code, while the remaining 25 percent is associated with the secondary NAICS code. Naturally, in instances where only one NAICS code was relevant, that code was attributed with 100 percent of the project activities.

Table 1. Example Showing Primary and Secondary NAICS Assignments and Corresponding Percentages.

\begin{tabular}{|c|c|c|c|c|c|c|c|}
\hline $\begin{array}{c}\text { Grant } \\
\text { Recipient }\end{array}$ & $\begin{array}{c}\text { Project } \\
\text { Description }\end{array}$ & $\begin{array}{c}\text { Primary } \\
\text { NAICS }\end{array}$ & $\begin{array}{c}\text { Primary NAICS } \\
\text { Description }\end{array}$ & $\begin{array}{c}\text { Primary } \\
\text { NAICS } \\
\%\end{array}$ & $\begin{array}{c}\text { Secondary } \\
\text { NAICS }\end{array}$ & $\begin{array}{c}\text { Secondary } \\
\text { NAICS } \\
\text { Description }\end{array}$ & $\begin{array}{c}\text { Secondary } \\
\text { NAICS \% }\end{array}$ \\
\hline $\begin{array}{c}\text { Description } \\
\text { of work } \\
\text { conducted }\end{array}$ & 518210 & $\begin{array}{c}\text { Data Processing, } \\
\text { Name and Related }\end{array}$ & Services & $75.00 \%$ & 541512 & $\begin{array}{c}\text { Computer Systems } \\
\text { Design Services }\end{array}$ & $25.00 \%$ \\
\hline
\end{tabular}

\subsection{3. $\quad$ BEA RIMS II Industry Multipliers}

The economic impact analysis uses the Bureau of Economic Analysis's (BEA's) Regional InputOutput Modeling System (RIMS II) model 6-digit, detailed industry code multipliers (hereafter referred to as "RIMS multipliers"). ${ }^{37}$ The RIMS II model shows how economic activity, such as that created through NIST PSCR's research mechanisms, results in other spending in the broader regional economy. BEA has compiled data for and linkages between industries that cover the U.S. economy, ${ }^{38}$ and for each industry, the RIMS II model shows how much input (in dollars) is taken from other industries in the economy and, conversely, how much each industry contributes (in dollars) to other industries. ${ }^{39}$ On top of this basic commodity flow structure, BEA also allocates the same values into "income" categories and "final demand" categories to allow for more detailed estimates of economic impact. ${ }^{40}$ This structure forms what BEA refers to as the "make-use" tables, used to derive multipliers for estimating economic impacts. RIMS II multipliers are either regional or industry-level in nature, and for this analysis, we used state level multipliers to reflect the change in each indicator for states participating in PSCR research.

\footnotetext{
${ }^{36}$ NAICS search web page: https://www.census.gov/naics/?99967

${ }^{37} \mathrm{https}$ ://www.bea.gov/resources/methodologies/RIMSII-user-guide

${ }^{38}$ https://apps.bea.gov/regional/rims/rimsii/download/64IndustryListB.pdf

${ }^{39}$ BEA RIMS II multipliers are not designed to be applied to international entities, therefore the economic impacts of NIST investments in international-based project and entities are not estimated in this analysis.

${ }^{40} \mathrm{~A}$ final aspect accounts for "imports" into a region.
} 
The types of multipliers of focus in the analysis include:

- Output multipliers reflect the change in the output of industries in a region for a one-dollar change in demand for a specific industry. That is, what is the total value of economic activity circulating through the states' economies generated by PSCR's R\&D investments?

- Value-added multipliers reflect the change in regional value-added (gross domestic product, GDP) for a one-dollar change in demand for a specific industry. That is, value-added indicates how much the regional economies grew over a period of time due to PSCR's R\&D investments.

- Earnings multipliers reflect the total change in household earnings in the region for a one-dollar change in demand for a specific industry. That is, what is the change in household earnings in the states' economies generated by PSCR's R\&D investments?

- Jobs multipliers reflect the change in the total number of jobs (full- and part-time) per a onemillion-dollar change in the demand for a specific industry. That is, what is the change in the number of full- and part-time jobs generated by each one-million-dollar change in the states' economic activity due to PSCR's R\&D investments?

\section{Identifying Industry Multipliers}

We used our NAICS code assignments to identify the RIMS II codes needed for the analysis by applying a crosswalk between NAICS and RIMS codes made available by BEA. ${ }^{41}$ This exercise resulted in 12 RIMS codes for use in the analysis, and Table 2 presents the counts of NIST PSCR project types by BEA industry category assigned by ERG. The left-hand column of the table provides the detailed industry codes used by BEA in the Regional Input-Output Modeling System (RIMS II). ${ }^{42}$ The counts of each project type having a RIMS II code are presented on the righthand side if the table, with the final column presented the total projects having a given RIMS II code. As the table indicates, the largest number of NIST PSCR projects can be categorized as "Scientific research and development services" (137), followed by "Custom computer programming services" (94) and "Computer systems design services" (93).

Table 2. Count of NIST PSCR Projects by RIMS II Industry Codes.

\begin{tabular}{|c|c|c|c|c|c|c|}
\hline \multirow[b]{2}{*}{$\begin{array}{l}\text { RIMS } \\
\text { Code }\end{array}$} & \multirow[b]{2}{*}{ Industry Represented by RIMS Code } & \multicolumn{5}{|c|}{ Count of Projects with RIMS Code } \\
\hline & & Grants & SBIR & $\begin{array}{c}\text { Prize } \\
\text { Challenges }\end{array}$ & $\begin{array}{l}\text { Internal } \\
\text { Research }\end{array}$ & Total \\
\hline 336411 & Aircraft manufacturing & 0 & 0 & 30 & 2 & 33 \\
\hline 518200 & Data processing, hosting, and related services & 11 & 0 & 37 & 4 & 52 \\
\hline 541300 & Architectural, engineering, and related services & 5 & 0 & 10 & 20 & 37 \\
\hline 541511 & Custom computer programming services & 21 & 0 & 62 & 11 & 94 \\
\hline 541512 & Computer systems design services & 28 & 2 & 58 & 5 & 93 \\
\hline 541700 & Scientific research and development services & 46 & 2 & 60 & 27 & 137 \\
\hline 561100 & Office administrative services & 0 & 0 & 0 & 18 & 18 \\
\hline $517 \mathrm{~A} 00$ & $\begin{array}{l}\text { Satellite, telecommunications resellers, and all } \\
\text { other telecommunications }\end{array}$ & 0 & 0 & 0 & 2 & 2 \\
\hline $813 \mathrm{~B} 00$ & $\begin{array}{l}\text { Civic, social, professional, and similar } \\
\text { organizations }\end{array}$ & 0 & 0 & 0 & 2 & 2 \\
\hline
\end{tabular}

\footnotetext{
${ }^{41}$ Bureau of Economic Analysis. Industry List A. RIMS II 369 Detailed Industry Codes.

${ }^{42}$ These codes are used in developing the economic impact estimates in Section 3.3.
} 


\begin{tabular}{|c|l|c|c|c|c|c|}
\hline 512100 & Motion picture and video industries & 0 & 0 & 5 & 0 & 5 \\
\hline 334511 & $\begin{array}{l}\text { Search, detection, and navigation instruments } \\
\text { manufacturing }\end{array}$ & 0 & 0 & 9 & 0 & 9 \\
\hline 611 B00 & Other educational services & 2 & 0 & 0 & 0 & 2 \\
\hline
\end{tabular}

ERG purchased the state-specific RIMS multipliers for the detailed codes appearing in Table 2 below for the analysis. ERG used the "Type II" final demand output, value-added, earnings, and jobs multipliers for use in the benefits calculation tool. ${ }^{43}$ The multipliers were added as separate tabs in the economic impact calculation tool spreadsheet and later compiled into a single tab for ease of use in the analysis.

\subsection{Economic Impact Calculations}

ERG developed a Microsoft Excel-based economic impact calculation tool to combine the multipliers and the NIST PSCR project investment data. Simplified versions of these calculation tools are depicted in Figure 4 (Grants, SBIR, and Internal Research) and Figure 5 (Prize Challenges). At a high level, these tools integrate the NIST PSCR economic data (see the green "Investment" a columns) and industry multipliers (see the teal "Multipliers - Final Demand (State-Specific)" columns) described in the previous sections to generate state-level economic impacts generated by each product/service. The economic impact on output, earnings, jobs, and value-added are calculated for each project-specific NIST PSCR investment, and the calculated economic impacts appear in the orange columns labeled "Economic Impacts (Final Demand) on Company's State."

\section{Calculation Steps}

Given that up to two industry codes were applied to each project, the actual economic impact calculations used in the analysis estimate impacts by calculating impacts twice: once for using the primary RIMS II multiplier and the percentage of project work attributed to that multiplier and again with the secondary RIMS multiplier and its associated the percentage of project work. Figure 6 shows how the economic impact calculations were set up to include primary and secondary RIM multiplier codes (columns $\mathrm{C}$ and $\mathrm{E}$ ) and the percentage of each that might be attributed to the project work.

- First, we calculate the economic impacts associate with the primary RIMS industry code. The tool multiplies the NIST PSCR investment (column G) by the primary RIMS multipliers (shown in columns $\mathrm{H}-\mathrm{K}$ ) and the percentage of work attributed with that multiplier (column D). This results in the economic impacts associated with the primary RIMS industry multiplier shown in columns L-O.

- Second, we repeat this entire process using the secondary RIMS industry code and percentage (columns E-F) would be used.

- Third, we sum the economic impacts results calculated for the primary and secondary RIMS industry codes to estimate total economic impacts for that project.

- Lastly, we update the total economic impacts from 2018 to 2020 dollars using the Bureau of Labor Statistics (BLS) Consumer Price Index (CPI). ${ }^{44}$

\footnotetext{
${ }^{43}$ The Type II multipliers account for inter-industry and household-spending, while Type I only accounts for inter-industry.

${ }^{44}$ https://www.bls.gov/data/inflation_calculator.htm
} 
Economic impacts were calculated for 60 grants, 2 SBIR awards, 166 prize challenges, and 170

funded internal research initiatives, comprised of 67 unique projects. ${ }^{45}$ The results of this analysis are presented below.

${ }^{45}$ These figures do not include international projects, for which ERG did not calculate economic impacts. 


\begin{tabular}{|c|c|c|c|c|c|c|c|c|c|c|c|c|}
\hline \multirow[b]{2}{*}{$\begin{array}{l}\text { Recipient/ } \\
\text { Awardee }\end{array}$} & \multirow[b]{2}{*}{ Project } & \multirow[b]{2}{*}{ State } & \multirow[b]{2}{*}{$\begin{array}{c}\text { RIMS II } \\
\text { Multipliers }\end{array}$} & \multirow[b]{2}{*}{$\begin{array}{c}\text { NIST } \\
\text { Investment } \\
\text { (\$) }\end{array}$} & \multicolumn{4}{|c|}{ Multipliers - Final Demand } & \multicolumn{4}{|c|}{ Economic Impacts (Final Demand) on Company's } \\
\hline & & & & & Output & Earnings & Jobs & $\begin{array}{l}\text { Value- } \\
\text { Added }\end{array}$ & $\begin{array}{c}\text { Output } \\
\text { (\$\$millions) }\end{array}$ & $\begin{array}{l}\text { Earnings } \\
\text { (\$\$millions) }\end{array}$ & Jobs & $\begin{array}{c}\text { Value- } \\
\text { Added } \\
\text { (S\$millions) }\end{array}$ \\
\hline & $\begin{array}{l}\text { NAICS } \\
\text { the rec } \\
\text { were b }\end{array}$ & $\begin{array}{l}\text { combin } \\
\text { cipient's } \\
\text { e used }\end{array}$ & $\begin{array}{l}\text { ed with } \\
\text { state } \\
\text { to assign }\end{array}$ & $\begin{array}{l}\text { Data } \\
\text { provided by }\end{array}$ & $\begin{array}{l}\text { Ave } \\
\text { BEA } \\
\text { sta }\end{array}$ & $\begin{array}{l}\text { lable at the } \\
\text { Reflect th } \\
\text { e level }\end{array}$ & $\begin{array}{l}\text { idustr } \\
\text { mpact }\end{array}$ & $\begin{array}{l}\text { vel from } \\
\text { the }\end{array}$ & $\begin{array}{l}\text { Reflect } \\
\text { each p }\end{array}$ & $\begin{array}{l}\text { the impact o } \\
\text { roject or prize }\end{array}$ & $\begin{array}{l}\text { the stat } \\
\text { halleng }\end{array}$ & $\begin{array}{l}\text { ssigned to } \\
\text { articipant }\end{array}$ \\
\hline
\end{tabular}

Fig. 4. Simplified Economic Impact Calculation Tool Used for Grants, SBIR, and Internal Research.

\begin{tabular}{|l|l|l|l|l|l|}
$\begin{array}{l}\text { Recipient/ } \\
\text { Awardee Project State Multipliers }\end{array}$ \\
\hline $\begin{array}{l}\text { NAICS combined with } \\
\text { the recipient's state } \\
\text { were used to assign }\end{array}$
\end{tabular}

Fig. 5. Simplified Economic Impact Calculation Tool Used for Prize Challenge Competitions.

* A 45 percent mark-up of the top awarded dollar amount in a given challenge was calculated then added to each award for that challenge to account for the participant's re-investment of the awarded amount into further product or solution development.

\begin{tabular}{|c|c|c|c|c|c|c|c|c|c|c|c|c|c|}
\hline B & C & D & $E$ & $\mathrm{~F}$ & G & H & $\mathbf{I}$ & J & K & L & M & $\mathrm{N}$ & $\mathrm{O}$ \\
\hline \multicolumn{5}{|c|}{ Industry Information } & \multirow[b]{3}{*}{$\begin{array}{l}\text { NIST } \\
\text { Investment } \\
\text { (\$) }\end{array}$} & \multicolumn{8}{|c|}{ Primary RIMS Multipliers and Economic Impacts } \\
\hline \multirow[b]{2}{*}{ Project } & & & Secondary & & & \multicolumn{4}{|c|}{$\begin{array}{l}\text { Final Demand Multipliers } \\
\text { (State-Specific) }\end{array}$} & \multicolumn{4}{|c|}{$\begin{array}{l}\text { Economic Impacts (Final Demand) on Awardee's } \\
\text { State }\end{array}$} \\
\hline & $\begin{array}{l}\text { Primary RIMS } \\
\text { II Detailed } \\
\text { Industry } \\
\text { Code }\end{array}$ & $\begin{array}{l}\text { Percent } \\
\text { Activities } \\
\text { Attributed } \\
\text { to Primary } \\
\text { RIMS }\end{array}$ & $\begin{array}{c}\text { RIMS II } \\
\text { Detailed } \\
\text { Industry } \\
\text { Code (If } \\
\text { Applicable) }\end{array}$ & $\begin{array}{c}\text { Percent } \\
\text { Activities } \\
\text { Attributed to } \\
\text { Secondary } \\
\text { RIMS }\end{array}$ & & Output & $\begin{array}{l}\text { Value- } \\
\text { Added }\end{array}$ & Earnings & Jobs & $\begin{array}{l}\text { Output } \\
\text { (\$2018 M) }\end{array}$ & $\begin{array}{l}\text { Value-Added } \\
\text { (\$2018 M) }\end{array}$ & $\begin{array}{l}\text { Earnings } \\
(\$ 2018 \mathrm{M})\end{array}$ & Jobs \\
\hline Project X & 518200 & $75 \%$ & 541700 & $25 \%$ & 0.18 & 1.9174 & 1.0213 & 0.4357 & 8.2702 & 0.26 & 0.14 & 0.06 & 1 \\
\hline
\end{tabular}

Fig. 6. Example of Calculation with Primary RIMS Multiplier. 


\subsection{Results}

This section presents the estimated economic impacts of NIST PSCR's four research mechanisms covered in this project. We present the impacts across all research mechanisms and then transition to a breakdown of impacts by each research mechanism.

Table 3 shows the economic impacts calculated across each of the research mechanisms. Our analysis found that NIST PSCR's investment in the four in-scope research mechanisms resulted in a total of:

- $\$ 509.84$ million in annual output (\$2020)

- \$431.19 million in annual value-added (\$2020)

- \$261.78 million in annual earnings and (\$2020)

- 4,280 new jobs.

Table 3. Total Economic Impact by Research Mechanism (Based on Multipliers).

\begin{tabular}{|c|c|c|c|c|c|}
\hline & Grants & SBIR & $\begin{array}{c}\text { Prize } \\
\text { Challenges }\end{array}$ & $\begin{array}{l}\text { Internal } \\
\text { Research } \\
\end{array}$ & Total \\
\hline Amount Invested (\$FY M) [a] & $\$ 73.94$ & $\$ 4.48$ & $\$ 3.50$ & $\$ 142.67$ & $\$ 224.59$ \\
\hline Amount Invested (\$2020 M) [b] & $\$ 68.07$ & $\$ 4.48$ & $\$ 3.44$ & $\$ 145.71$ & $\$ 221.71$ \\
\hline Total Output (\$2020 M) & $\$ 139.49$ & $\$ 9.13$ & $\$ 29.10$ & $\$ 332.12$ & $\$ 509.84$ \\
\hline Value-Added (\$2020 M) & $\$ 211.22$ & $\$ 5.88$ & $\$ 18.28$ & $\$ 195.81$ & $\$ 431.19$ \\
\hline Earnings (\$2020 M) & $\$ 123.36$ & $\$ 3.42$ & $\$ 10.65$ & $\$ 124.35$ & $\$ 261.78$ \\
\hline Jobs & 1,967 & 53 & 169 & 2,091 & 4,280 \\
\hline
\end{tabular}

${ }^{a}$ This sum reflects dollars invested by NIST PSCR for the original fiscal year of the investment and sums across fiscal years FY16-FY20 rather than putting all dollars in the same fiscal year.

${ }^{\mathrm{b}}$ This amount invested excludes 9 international awards, totaling $\$ 7.98 \mathrm{M}$. For this project, we only included projects with domestic multipliers in the economic impact analysis.

Figure 7 shows how the funding provided through Public Safety Trust Fund (PSTF) allocations was applied by NIST PSCR to achieve direct and indirect impacts. Viewing from top to bottom, the figure shows how up to $\$ 300$ million in PSTF allocations flow through NIST PSCR to internal and external research mechanisms. These research efforts generate direct economic impacts, like increased household earnings and jobs, in the states in which research occurs as well as improved public safety communications. The improved public safety communications then result in indirect impacts associated with improved support of public safety communities and the citizens they serve. 


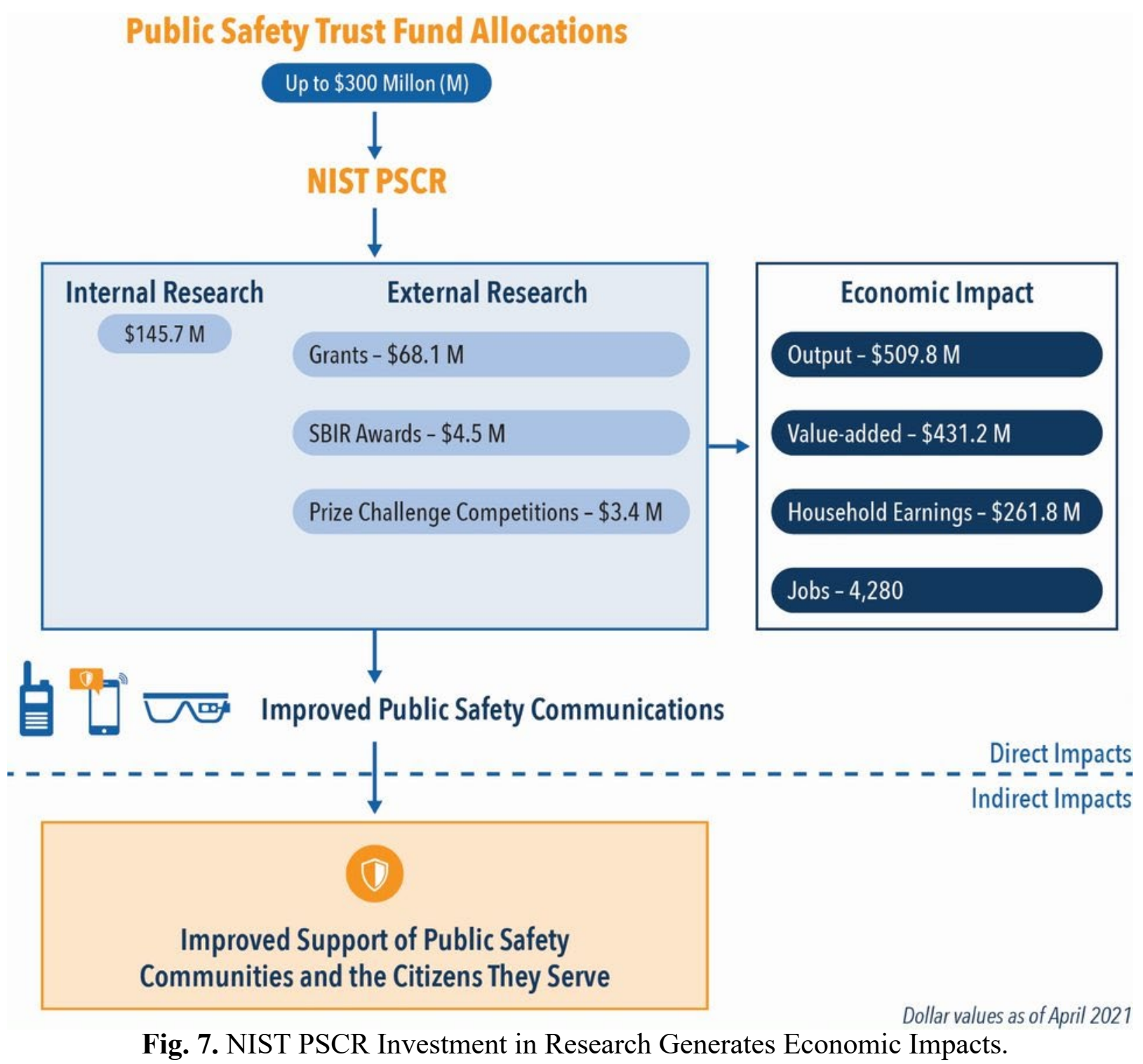

The breakdown of NIST PSCR investment and the resulting economic impacts across the six PSCR research portfolios is presented in Table 4 . When comparing the NIST PSCR investment to economic impacts generated by that investment, the three portfolios that generated the largest economic output per dollar invested were Resilient Systems ( $\$ 2.6$ per $\$ 1$ invested), Security $(\$ 2.5$ per $\$ 1$ invested), and UI/UX (\$2.4 per \$1 invested). ${ }^{46}$

\footnotetext{
${ }^{46}$ The difference in economic impact generated by each portfolio is due to the fact that each portfolio contains a mixture of different project-types associated with different industry sectors, and the work activities conducted for each portfolio occur in different geographies. This means that the PSCR dollars invested in each portfolio filter through economic impact multipliers that are both state- and sector-specific. Thus, the multipliers applied to each portfolio differ, and the application of these differing multipliers result in varying economic impacts for a \$1 PSCR investment in a given portfolio.
} 
Table 4. Impact by NIST PSCR Portfolio (Based on Multipliers).*

\begin{tabular}{|c|c|c|c|c|c|c|}
\hline & $\begin{array}{l}\text { Number of } \\
\text { Awards/ } \\
\text { Projects [a] }\end{array}$ & $\begin{array}{c}\text { NIST } \\
\text { Investment } \\
\text { (\$2020 M) }\end{array}$ & $\begin{array}{c}\text { Output } \\
\text { (\$2020 M) }\end{array}$ & $\begin{array}{c}\text { Value- } \\
\text { Added } \\
(\$ 2020 \mathrm{M})\end{array}$ & $\begin{array}{l}\text { Earnings } \\
\text { (\$2020 M) }\end{array}$ & Jobs \\
\hline Data Analytics & 63 & $\$ 16.35$ & $\$ 37.50$ & $\$ 48.72$ & $\$ 27.10$ & 450 \\
\hline Location Based Services & 42 & $\$ 21.36$ & $\$ 45.15$ & $\$ 39.32$ & $\$ 22.86$ & 364 \\
\hline Mission Critical Voice & 62 & $\$ 36.06$ & $\$ 76.35$ & $\$ 80.78$ & $\$ 47.45$ & 740 \\
\hline Resilient Systems & 55 & $\$ 9.28$ & $\$ 24.45$ & $\$ 39.31$ & $\$ 23.50$ & 361 \\
\hline Security & 47 & $\$ 8.18$ & $\$ 20.26$ & $\$ 12.06$ & $\$ 7.22$ & 117 \\
\hline UI/UX & 101 & $\$ 22.76$ & $\$ 54.96$ & $\$ 64.11$ & $\$ 38.99$ & 626 \\
\hline Support \& Misc. Projects & 20 & $\$ 94.09$ & $\$ 218.10$ & $\$ 127.42$ & $\$ 81.54$ & 1,393 \\
\hline Open Innovation Team & 10 & $\$ 13.62$ & $\$ 33.09$ & $\$ 19.47$ & $\$ 13.13$ & 228 \\
\hline Total & 398 & $\$ 221.7$ & $\$ 509.8$ & $\$ 431.2$ & $\$ 261.8$ & 4,280 \\
\hline
\end{tabular}

*In some instances, NIST PSCR Prize challenges were associated with all NIST PSCR portfolios rather than a single NIST PSCR portfolio. In these instances, the NIST PSCR investment for the award is divided evenly across each of the portfolios in order to evenly distribute the economic impacts of those awards.

${ }^{a}$ This excludes internationals awards/projects since they are not included in the analysis. Total awards/project including international projects is 407 .

Table 5 shows the economic impacts by state across all research mechanisms. States with the greatest number of awards or projects include Colorado (CO), Maryland (MD), California, and Texas. NIST PSCR's internal research work is responsible for the high number of projects in $\mathrm{CO}$ and $\mathrm{MD}$, as this research takes place at NIST campuses in both states.

Table 5. Economic Impacts by State Across Research Mechanisms.

\begin{tabular}{|c|r|r|r|r|r|}
\hline State & $\begin{array}{c}\text { Number of } \\
\text { Awards/Projects }\end{array}$ & $\begin{array}{c}\text { Output } \\
\mathbf{( \$ 2 0 2 0} \mathbf{M})\end{array}$ & $\begin{array}{c}\text { Value-Added } \\
\mathbf{( \$ 2 0 2 0} \mathbf{M})\end{array}$ & $\begin{array}{c}\text { Earnings } \mathbf{( \$ 2 0 2 0} \\
\mathbf{M})\end{array}$ & Jobs \\
\hline AR & 1 & $\$ 0.13$ & $\$ 0.09$ & $\$ 0.06$ & 1 \\
\hline $\mathrm{CA}$ & 48 & $\$ 24.22$ & $\$ 28.70$ & $\$ 17.47$ & 250 \\
\hline $\mathrm{CO}$ & 110 & $\$ 304.25$ & $\$ 183.34$ & $\$ 117.40$ & 1984 \\
\hline $\mathrm{CT}$ & 1 & $\$ 0.26$ & $\$ 0.47$ & $\$ 0.22$ & 4 \\
\hline DC & 3 & $\$ 1.90$ & $\$ 1.08$ & $\$ 0.22$ & 3 \\
\hline FL & 12 & $\$ 3.02$ & $\$ 3.94$ & $\$ 2.45$ & 44 \\
\hline GA & 10 & $\$ 14.38$ & $\$ 21.26$ & $\$ 12.70$ & 230 \\
\hline IL & 13 & $\$ 1.42$ & $\$ 0.93$ & $\$ 0.57$ & 8 \\
\hline IN & 1 & $\$ 17.43$ & $\$ 9.91$ & $\$ 5.96$ & 93 \\
\hline IA & 2 & $\$ 0.10$ & $\$ 0.06$ & $\$ 0.04$ & 1 \\
\hline KS & 1 & $\$ 0.46$ & $\$ 0.24$ & $\$ 0.11$ & 2 \\
\hline KY & 80 & $\$ 0.22$ & $\$ 0.11$ & $\$ 0.05$ & 1 \\
\hline MD & 6 & $\$ 34.57$ & $\$ 24.18$ & $\$ 13.37$ & 205 \\
\hline MA & 7 & $\$ 6.00$ & $\$ 7.74$ & $\$ 4.56$ & 64 \\
\hline MI & 1 & $\$ 0.20$ & $\$ 14.28$ & $\$ 8.76$ & 148 \\
\hline MN & 1 & $\$ 0.33$ & $\$ 0.80$ & $\$ 0.52$ & 10 \\
\hline MS & 1 & $\$ 0.19$ & $\$ 0.09$ & $\$ 0.05$ & 1 \\
\hline MT & & & & & \\
\hline
\end{tabular}




\begin{tabular}{|c|c|c|c|c|c|}
\hline State & $\begin{array}{c}\text { Number of } \\
\text { Awards/Projects }\end{array}$ & $\begin{array}{c}\text { Output } \\
\text { (\$2020 M) }\end{array}$ & $\begin{array}{l}\text { Value-Added } \\
\text { (\$2020 M) }\end{array}$ & $\begin{array}{c}\text { Earnings (\$2020 } \\
\text { M) }\end{array}$ & Jobs \\
\hline NJ & 7 & $\$ 10.48$ & $\$ 17.74$ & $\$ 9.93$ & 144 \\
\hline NY & 9 & $\$ 12.12$ & $\$ 14.56$ & $\$ 7.91$ & 112 \\
\hline $\mathrm{NC}$ & 14 & $\$ 9.11$ & $\$ 18.79$ & $\$ 11.62$ & 192 \\
\hline ND & 1 & $\$ 0.05$ & $\$ 0.01$ & $\$ 0.01$ & 0 \\
\hline $\mathrm{OH}$ & 6 & $\$ 2.60$ & $\$ 4.56$ & $\$ 2.48$ & 48 \\
\hline $\mathrm{OK}$ & 1 & $\$ 0.13$ & $\$ 0.08$ & $\$ 0.05$ & 1 \\
\hline OR & 1 & $\$ 3.30$ & $\$ 4.22$ & $\$ 2.31$ & 40 \\
\hline $\mathrm{PA}$ & 11 & $\$ 10.21$ & $\$ 15.03$ & $\$ 8.97$ & 139 \\
\hline $\mathrm{TN}$ & 1 & $\$ 0.99$ & $\$ 2.11$ & $\$ 1.02$ & 19 \\
\hline $\mathrm{TX}$ & 23 & $\$ 24.75$ & $\$ 38.17$ & $\$ 22.33$ & 375 \\
\hline VA & 14 & $\$ 13.85$ & $\$ 15.00$ & $\$ 8.37$ & 128 \\
\hline WA & 8 & $\$ 4.13$ & $\$ 3.67$ & $\$ 2.28$ & 32 \\
\hline
\end{tabular}

\subsubsection{Results by Research Mechanism}

The estimates economic impacts generated by each of the four NIST PSCR research mechanisms are presented below. For each mechanism, we present the impacts by portfolio and state in tabular form.

\subsubsection{Grants}

Table 6. Economic Impacts Generated by Grants by Portfolio.

\begin{tabular}{|l|r|r|r|r|r|r|}
\hline & \multicolumn{1}{|c|}{$\begin{array}{c}\text { NIST } \\
\text { Number of } \\
\text { Awards }\end{array}$} & $\begin{array}{c}\text { Investment } \\
\mathbf{( \$ 2 0 2 0} \mathbf{M})\end{array}$ & $\begin{array}{c}\text { Output } \\
(\mathbf{\$ 2 0 2 0} \mathbf{M})\end{array}$ & $\begin{array}{c}\text { Value-Added } \\
\mathbf{( \$ 2 0 2 0} \mathbf{M})\end{array}$ & $\begin{array}{c}\text { Earnings } \\
\mathbf{( \$ 2 0 2 0} \\
\mathbf{M})\end{array}$ & \multicolumn{1}{|c|}{ Jobs } \\
\hline Data Analytics & 11 & $\$ 12.45$ & $\$ 26.01$ & $\$ 41.40$ & $\$ 22.88$ & 384 \\
\hline Location Based Services & 13 & $\$ 16.92$ & $\$ 33.42$ & $\$ 32.22$ & $\$ 18.50$ & 294 \\
\hline Mission Critical Voice & 12 & $\$ 16.85$ & $\$ 33.85$ & $\$ 55.12$ & $\$ 32.04$ & 496 \\
\hline Resilient Systems & 8 & $\$ 8.00$ & $\$ 17.01$ & $\$ 35.06$ & $\$ 21.13$ & 324 \\
\hline Security & 1 & $\$ 1.50$ & $\$ 3.38$ & $\$ 1.92$ & $\$ 1.14$ & 21 \\
\hline UI/UX & 15 & $\$ 12.34$ & $\$ 25.82$ & $\$ 45.50$ & $\$ 27.66$ & 448 \\
\hline Total & $\mathbf{6 0}$ & $\mathbf{\$ 6 8 . 0 7}$ & $\mathbf{\$ 1 3 9 . 4 9}$ & $\mathbf{\$ 2 1 1 . 2 2}$ & $\mathbf{\$ 1 2 3 . 3 6}$ & $\mathbf{1 , 9 6 7}$ \\
\hline
\end{tabular}

Table 7. Economic Impacts Generated by Grants by State.

\begin{tabular}{|c|c|c|c|c|c|c|}
\hline State & $\begin{array}{l}\text { Number of } \\
\text { Awards }\end{array}$ & $\begin{array}{c}\text { NIST PSCR } \\
\text { Investment } \\
(\$ 2020 \mathrm{M})\end{array}$ & $\begin{array}{c}\text { Output } \\
\text { (\$2020 M) }\end{array}$ & $\begin{array}{c}\text { Value- } \\
\text { Added } \\
(\mathbf{\$ 2 0 2 0} \mathrm{M})\end{array}$ & $\begin{array}{l}\text { Earnings } \\
\text { (\$2020 M) }\end{array}$ & Jobs \\
\hline $\mathrm{CA}$ & 5 & $\$ 7.15$ & $\$ 14.95$ & $\$ 22.81$ & $\$ 13.99$ & 199 \\
\hline $\mathrm{CO}$ & 2 & $\$ 2.20$ & $\$ 4.81$ & $\$ 7.52$ & $\$ 4.68$ & 72 \\
\hline $\mathrm{CT}$ & 1 & $\$ 0.14$ & $\$ 0.26$ & $\$ 0.47$ & $\$ 0.22$ & 4 \\
\hline $\mathrm{DC}$ & 2 & $\$ 1.33$ & $\$ 1.87$ & $\$ 1.06$ & $\$ 0.21$ & 3 \\
\hline FL & 2 & $\$ 0.65$ & $\$ 1.38$ & $\$ 2.92$ & $\$ 1.84$ & 33 \\
\hline GA & 3 & $\$ 5.72$ & $\$ 12.55$ & $\$ 20.09$ & $\$ 12.00$ & 218 \\
\hline IN & 2 & $\$ 8.09$ & $\$ 15.95$ & $\$ 8.99$ & $\$ 5.40$ & 83 \\
\hline MA & 3 & $\$ 2.81$ & $\$ 5.63$ & $\$ 7.51$ & $\$ 4.44$ & 62 \\
\hline MD & 2 & $\$ 1.69$ & $\$ 3.16$ & $\$ 4.72$ & $\$ 2.26$ & 38 \\
\hline MI & 6 & $\$ 4.56$ & $\$ 9.13$ & $\$ 14.24$ & $\$ 8.74$ & 148 \\
\hline
\end{tabular}




\begin{tabular}{|c|c|c|c|c|c|c|}
\hline State & $\begin{array}{c}\text { Number of } \\
\text { Awards }\end{array}$ & $\begin{array}{l}\text { NIST PSCR } \\
\text { Investment } \\
\text { (\$2020 M) }\end{array}$ & $\begin{array}{l}\text { Output } \\
(\$ 2020 \mathrm{M})\end{array}$ & $\begin{array}{c}\text { Value- } \\
\text { Added } \\
(\$ 2020 \mathrm{M})\end{array}$ & $\begin{array}{l}\text { Earnings } \\
\text { (\$2020 M) }\end{array}$ & Jobs \\
\hline MS & 1 & $\$ 0.18$ & $\$ 0.33$ & $\$ 0.80$ & $\$ 0.52$ & 10 \\
\hline $\mathrm{NC}$ & 5 & $\$ 3.76$ & $\$ 7.90$ & $\$ 18.05$ & $\$ 11.20$ & 184 \\
\hline $\mathrm{NJ}$ & 3 & $\$ 4.53$ & $\$ 9.54$ & $\$ 17.15$ & $\$ 9.60$ & 139 \\
\hline NY & 3 & $\$ 6.10$ & $\$ 11.59$ & $\$ 14.21$ & $\$ 7.72$ & 109 \\
\hline $\mathrm{OH}$ & 2 & $\$ 0.94$ & $\$ 1.94$ & $\$ 4.18$ & $\$ 2.28$ & 43 \\
\hline OR & 1 & $\$ 1.75$ & $\$ 3.30$ & $\$ 4.22$ & $\$ 2.31$ & 40 \\
\hline PA & 5 & $\$ 4.71$ & $\$ 9.64$ & $\$ 14.68$ & $\$ 8.77$ & 136 \\
\hline $\mathrm{TN}$ & 1 & $\$ 0.46$ & $\$ 0.99$ & $\$ 2.11$ & $\$ 1.02$ & 19 \\
\hline $\mathrm{TX}$ & 6 & $\$ 6.42$ & $\$ 15.17$ & $\$ 32.39$ & $\$ 18.68$ & 314 \\
\hline VA & 3 & $\$ 3.31$ & $\$ 6.37$ & $\$ 10.13$ & $\$ 5.64$ & 87 \\
\hline WA & 2 & $\$ 1.55$ & $\$ 3.03$ & $\$ 2.95$ & $\$ 1.84$ & 26 \\
\hline Total & 60 & $\$ 68.07$ & $\$ 139.49$ & $\$ 211.22$ & $\$ 123.36$ & 1,967 \\
\hline
\end{tabular}

\subsubsection{SBIR}

Table 8. Economic Impacts Generated by SBIR Phase 3 Contract by Portfolio.

\begin{tabular}{|l|r|r|r|r|r|r|}
\hline & $\begin{array}{c}\text { NIST } \\
\text { Number of } \\
\text { Awards }\end{array}$ & $\begin{array}{c}\text { PSCR } \\
\text { Investment } \\
\mathbf{( \$ 2 0 2 0} \mathbf{M})\end{array}$ & $\begin{array}{c}\text { Output } \\
\mathbf{( \$ 2 0 2 0} \mathbf{M})\end{array}$ & $\begin{array}{c}\text { Value-Added } \\
\mathbf{( \$ 2 0 2 0} \mathbf{M})\end{array}$ & $\begin{array}{c}\text { Earnings } \\
\mathbf{( \$ 2 0 2 0} \\
\mathbf{M})\end{array}$ & \multicolumn{1}{|c|}{ Jobs } \\
\hline Data Analytics & 0 & $\$ 0.00$ & $\$ 0.00$ & $\$ 0.00$ & $\$ 0.00$ & 0 \\
\hline Location Based Services & 0 & $\$ 0.00$ & $\$ 0.00$ & $\$ 0.00$ & $\$ 0.00$ & 0 \\
\hline Mission Critical Voice & 1 & $\$ 2.99$ & $\$ 5.70$ & $\$ 3.71$ & $\$ 2.10$ & 32 \\
\hline Resilient Systems & 0 & $\$ 0.00$ & $\$ 0.00$ & $\$ 0.00$ & $\$ 0.00$ & 0 \\
\hline Security & 0 & $\$ 0.00$ & $\$ 0.00$ & $\$ 0.00$ & $\$ 0.00$ & 0 \\
\hline UI/UX & 1 & $\$ 1.49$ & $\$ 3.43$ & $\$ 2.17$ & $\$ 1.33$ & 21 \\
\hline Total & $\mathbf{2}$ & $\mathbf{\$ 4 . 4 8}$ & $\mathbf{\$ 9 . 1 3}$ & $\mathbf{\$ 5 . 8 8}$ & $\mathbf{\$ 3 . 4 2}$ & $\mathbf{5 3}$ \\
\hline
\end{tabular}

Table 9. Economic Impacts Generated by SBIR Phase 3 Contracts by State.

\begin{tabular}{|c|c|c|c|c|c|c|}
\hline State & $\begin{array}{c}\text { Number of } \\
\text { Awards }\end{array}$ & $\begin{array}{c}\text { NIST } \\
\text { PSCR } \\
\text { Investment } \\
(\$ 2020 \mathrm{M})\end{array}$ & $\begin{array}{c}\text { Output } \\
\text { (\$2020 M) }\end{array}$ & $\begin{array}{l}\text { Value-Added } \\
\text { (\$2020 M) }\end{array}$ & $\begin{array}{c}\text { Earnings } \\
(\$ 2020 \\
M)\end{array}$ & Jobs \\
\hline $\mathrm{TX}$ & 1 & $\$ 1.49$ & $\$ 3.43$ & $\$ 2.17$ & $\$ 1.33$ & 21 \\
\hline VA & 1 & $\$ 2.99$ & $\$ 5.70$ & $\$ 3.71$ & $\$ 2.10$ & 32 \\
\hline Total & 2 & $\$ 4.48$ & $\$ 9.13$ & $\$ 5.88$ & $\$ 3.42$ & 53 \\
\hline
\end{tabular}




\subsubsection{Prize Challenge Competitions}

Table 10. Economic Impacts Generated by Prize Challenge Competitions by Portfolio.

\begin{tabular}{|c|c|c|c|c|c|c|}
\hline & $\begin{array}{c}\text { Number of } \\
\text { Awards } \\
\end{array}$ & $\begin{array}{c}\text { NIST } \\
\text { PSCR } \\
\text { Investment } \\
(\$ 2020 \mathrm{M}) \\
\end{array}$ & $\begin{array}{c}\text { Output } \\
(\$ 2020 \mathrm{M})\end{array}$ & $\begin{array}{c}\text { Value-Added } \\
(\$ 2020 \mathrm{M})\end{array}$ & $\begin{array}{c}\text { Earnings } \\
(\$ 2020 \\
\mathrm{M}) \\
\end{array}$ & Jobs \\
\hline Data Analytics & 24 & $\$ 0.69$ & $\$ 5.23$ & $\$ 3.29$ & $\$ 1.88$ & 31 \\
\hline Location Based Services & 0 & $\$ 0.28$ & $\$ 2.56$ & $\$ 1.70$ & $\$ 1.02$ & 16 \\
\hline Mission Critical Voice & 0 & $\$ 0.28$ & $\$ 2.56$ & $\$ 1.70$ & $\$ 1.02$ & 16 \\
\hline Resilient Systems & 29 & $\$ 0.75$ & $\$ 6.23$ & $\$ 3.55$ & $\$ 1.92$ & 30 \\
\hline Security & 5 & $\$ 0.34$ & $\$ 3.30$ & $\$ 2.19$ & $\$ 1.31$ & 20 \\
\hline UI/UX & 56 & $\$ 1.10$ & $\$ 9.22$ & $\$ 5.86$ & $\$ 3.51$ & 56 \\
\hline Multiple (all) [a] & 52 & & & & & \\
\hline Total & 166 & $\$ 3.44$ & $\$ 29.10$ & $\$ 18.28$ & $\$ 10.65$ & 169 \\
\hline
\end{tabular}

${ }^{a}$ In some instances, NIST PSCR Prize challenges were associated with all PSCR portfolios rather than a single portfolio. In these instances, the NIST PSCR investment for the award is divided evenly across each of the portfolios in order to evenly distribute the economic impacts of those awards.

Table 11. Economic Impacts Generated by Prize Challenge Competitions by State.

\begin{tabular}{|c|c|c|c|c|c|c|}
\hline State & $\begin{array}{c}\text { Number of } \\
\text { Awards }\end{array}$ & $\begin{array}{c}\text { NIST } \\
\text { PSCR } \\
\text { Investment } \\
(\$ 2020 \mathrm{M}) \\
\end{array}$ & $\begin{array}{l}\text { Output } \\
(\$ 2020 \mathrm{M})\end{array}$ & $\begin{array}{l}\text { Value-Added } \\
(\$ 2020 \mathrm{M})\end{array}$ & $\begin{array}{c}\text { Earnings } \\
\text { (\$2020 } \\
\mathrm{M})\end{array}$ & Jobs \\
\hline $\mathrm{AR}$ & 1 & $\$ 0.00$ & $\$ 0.13$ & $\$ 0.09$ & $\$ 0.06$ & 1 \\
\hline $\mathrm{CA}$ & 43 & $\$ 1.15$ & $\$ 9.27$ & $\$ 5.88$ & $\$ 3.48$ & 51 \\
\hline $\mathrm{CO}$ & 10 & $\$ 0.29$ & $\$ 2.10$ & $\$ 1.35$ & $\$ 0.82$ & 13 \\
\hline $\mathrm{DC}$ & 1 & $\$ 0.00$ & $\$ 0.03$ & $\$ 0.02$ & $\$ 0.00$ & 0 \\
\hline FL & 10 & $\$ 0.21$ & $\$ 1.64$ & $\$ 1.02$ & $\$ 0.61$ & 11 \\
\hline GA & 7 & $\$ 0.17$ & $\$ 1.83$ & $\$ 1.17$ & $\$ 0.71$ & 12 \\
\hline IA & 1 & $\$ 0.01$ & $\$ 0.10$ & $\$ 0.06$ & $\$ 0.04$ & 1 \\
\hline IL & 4 & $\$ 0.04$ & $\$ 1.42$ & $\$ 0.93$ & $\$ 0.57$ & 8 \\
\hline IN & 11 & $\$ 0.27$ & $\$ 1.48$ & $\$ 0.93$ & $\$ 0.56$ & 10 \\
\hline $\mathrm{KS}$ & 2 & $\$ 0.09$ & $\$ 0.46$ & $\$ 0.24$ & $\$ 0.11$ & 2 \\
\hline KY & 1 & $\$ 0.02$ & $\$ 0.22$ & $\$ 0.11$ & $\$ 0.05$ & 1 \\
\hline MA & 3 & $\$ 0.05$ & $\$ 0.38$ & $\$ 0.23$ & $\$ 0.12$ & 2 \\
\hline MD & 10 & $\$ 0.17$ & $\$ 1.12$ & $\$ 0.72$ & $\$ 0.40$ & 6 \\
\hline MI & 1 & $\$ 0.01$ & $\$ 0.07$ & $\$ 0.04$ & $\$ 0.02$ & 0 \\
\hline $\mathrm{MN}$ & 1 & $\$ 0.00$ & $\$ 0.06$ & $\$ 0.03$ & $\$ 0.01$ & 0 \\
\hline MT & 1 & $\$ 0.02$ & $\$ 0.19$ & $\$ 0.09$ & $\$ 0.05$ & 1 \\
\hline $\mathrm{NC}$ & 9 & $\$ 0.13$ & $\$ 1.20$ & $\$ 0.74$ & $\$ 0.42$ & 8 \\
\hline ND & 1 & $\$ 0.01$ & $\$ 0.05$ & $\$ 0.01$ & $\$ 0.01$ & 0 \\
\hline $\mathrm{NJ}$ & 4 & $\$ 0.13$ & $\$ 0.95$ & $\$ 0.60$ & $\$ 0.32$ & 5 \\
\hline NY & 6 & $\$ 0.06$ & $\$ 0.53$ & $\$ 0.34$ & $\$ 0.18$ & 3 \\
\hline $\mathrm{OH}$ & 4 & $\$ 0.07$ & $\$ 0.66$ & $\$ 0.38$ & $\$ 0.20$ & 5 \\
\hline $\mathrm{OK}$ & 1 & $\$ 0.02$ & $\$ 0.13$ & $\$ 0.08$ & $\$ 0.05$ & 1 \\
\hline PA & 6 & $\$ 0.09$ & $\$ 0.56$ & $\$ 0.35$ & $\$ 0.20$ & 3 \\
\hline $\mathrm{TX}$ & 12 & $\$ 0.15$ & $\$ 1.66$ & $\$ 1.00$ & $\$ 0.58$ & 9 \\
\hline VA & 10 & $\$ 0.22$ & $\$ 1.78$ & $\$ 1.15$ & $\$ 0.64$ & 10 \\
\hline WA & 6 & $\$ 0.07$ & $\$ 1.10$ & $\$ 0.72$ & $\$ 0.44$ & 6 \\
\hline Total & 166 & $\$ 3.44$ & $\$ 29.10$ & $\$ 18.28$ & $\$ 10.65$ & 169 \\
\hline
\end{tabular}




\subsubsection{Internal Research}

Table 12. Economic Impacts Generated by Internal NIST PSCR Research by Portfolio.

\begin{tabular}{|c|c|c|c|c|c|c|}
\hline & $\begin{array}{c}\text { Number } \\
\text { of } \\
\text { Projects } \\
\text { [a] }\end{array}$ & $\begin{array}{l}\text { NIST PSCR } \\
\text { Investment } \\
\text { (\$2020 M) }\end{array}$ & $\begin{array}{l}\text { Output } \\
(\$ 2020 \mathrm{M})\end{array}$ & $\begin{array}{l}\text { Value-Added } \\
\text { (\$2020 M) }\end{array}$ & $\begin{array}{l}\text { Earnings } \\
(\$ 2020 \mathrm{M})\end{array}$ & Jobs \\
\hline Data Analytics & 19 & $\$ 3.21$ & $\$ 6.26$ & $\$ 4.04$ & $\$ 2.33$ & 36 \\
\hline $\begin{array}{l}\text { Location Based } \\
\text { Services }\end{array}$ & 20 & $\$ 4.16$ & $\$ 9.16$ & $\$ 5.41$ & $\$ 3.34$ & 54 \\
\hline Mission Critical Voice & 40 & $\$ 15.94$ & $\$ 34.23$ & $\$ 20.25$ & $\$ 12.29$ & 196 \\
\hline Resilient Systems & 9 & $\$ 0.54$ & $\$ 1.21$ & $\$ 0.70$ & $\$ 0.45$ & 8 \\
\hline Security & 32 & $\$ 6.34$ & $\$ 13.58$ & $\$ 7.95$ & $\$ 4.77$ & 76 \\
\hline $\mathrm{UI} / \mathrm{UX}$ & 20 & $\$ 7.83$ & $\$ 16.48$ & $\$ 10.58$ & $\$ 6.49$ & 100 \\
\hline $\begin{array}{l}\text { Support \& Misc. } \\
\text { Projects }\end{array}$ & 20 & $\$ 94.09$ & $\$ 218.10$ & $\$ 127.42$ & $\$ 81.54$ & 1,393 \\
\hline Open Innovation Team & 10 & $\$ 13.62$ & $\$ 33.09$ & $\$ 19.47$ & $\$ 13.13$ & 228 \\
\hline Total & 170 & $\$ 145.71$ & $\$ 332.12$ & $\$ 195.81$ & $\$ 124.35$ & 2,091 \\
\hline
\end{tabular}

${ }^{a}$ These are not unique projects. Number of awards may include multiple instances of a project over multiple fiscal years and locations.

Table 13. Economic Impacts Generated by Internal NIST PSCR Research by State.

\begin{tabular}{|l|r|r|r|r|r|r|}
\hline State & $\begin{array}{c}\text { Number } \\
\text { of } \\
\text { Projects }\end{array}$ & $\begin{array}{c}\text { NIST PSCR } \\
\text { Investment } \\
\mathbf{( \$ 2 0 2 0} \mathbf{M})\end{array}$ & $\begin{array}{c}\text { Output } \\
\mathbf{( \$ 2 0 2 0} \mathbf{M})\end{array}$ & $\begin{array}{c}\text { Value-Added } \\
\mathbf{( \$ 2 0 2 0} \mathbf{M})\end{array}$ & \multicolumn{1}{c|}{$\begin{array}{c}\text { Earnings } \\
\mathbf{( \$ 2 0 2 0 ~ M )}\end{array}$} & \multicolumn{1}{|c|}{ Jobs } \\
\hline CO & 98 & $\$ 128.57$ & $\$ 297.34$ & $\$ 174.47$ & $\$ 111.90$ & 1,899 \\
\hline MD & 68 & $\$ 15.40$ & $\$ 30.29$ & $\$ 18.73$ & $\$ 10.72$ & 161 \\
\hline TX & 4 & $\$ 1.74$ & $\$ 4.50$ & $\$ 2.61$ & $\$ 1.74$ & 31 \\
\hline Total & $\mathbf{1 7 0}$ & $\mathbf{\$ 1 4 5 . 7 1}$ & $\mathbf{\$ 3 3 2 . 1 2}$ & $\mathbf{\$ 1 9 5 . 8 1}$ & $\mathbf{\$ 1 2 4 . 3 5}$ & $\mathbf{2 , 0 9 1}$ \\
\hline
\end{tabular}




\section{References}

[1] Glenn J.E., Shaw I, Leh M, (2020) Public Safety Communications Research Division Impact Report: Fiscal Years 2017-2019. National Institute of Standards and Technology, Boulder, CO), NIST Special Publication (SP) 1248. https://doi.org/10.6028/NIST.SP.1248.

[2] Bureau of Economic Analysis (2018) Regional Input-Output Modeling System (RIMS II) User's Guide. (Department of Commerce, Suitland, M.D.) Available at https://www.bea.gov/resources/methodologies/RIMSII-user-guide.

[3] National Institute of Standards and Technology (2017) Public Safety Innovation Accelerator Program 2017. Available at https://www.nist.gov/ctl/pscr/fundingopportunities/past-funding-opportunities/psiap-2017

[4] National Institute of Standards and Technology (2018) PSIAP Point Cloud City. Available at https://www.nist.gov/ctl/pscr/funding-opportunities/pastfunding-opportunities/psiap-point-cloud-city

[5] National Institute of Standards and Technology (2017) PSIAP User Interface. Available at https://www.nist.gov/ctl/pscr/funding-opportunities/pastfunding-opportunities/psiap-user-interface

[6] National Institute of Standards and Technology (2018) PSIAP i-Axis. Available at https://www.nist.gov/ctl/pscr/funding-opportunities/past-fundingopportunities/psiap-i-axis

[7] National Institute of Standards and Technology (2019) PSIAP MCV Test Equipment. Available at https://www.nist.gov/ctl/pscr/funding-opportunities/pastfunding-opportunities/psiap-mcv-test-equipment

[8] National Institute of Standards and Technology (2018) PSIAP MCV QoE. Available at https://www.nist.gov/ctl/pscr/funding-opportunities/past-fundingopportunities/psiap-mcv-qoe

[9] National Institute of Standards and Technology (2020) PSIAP Augmented Reality. Available at $\mathrm{https://www.nist.gov/ctl/pscr/psiap-augmented-reality}$

[10] National Institute of Standards and Technology (2019) PSIAP First Responder 3D Indoor Tracking Prize. Available at https://www.nist.gov/ctl/pscr/psiap-firstresponder-3d-indoor-tracking.

[11] National Institute of Standards and Technology (2020) PSIAP TABA \& Demonstration. Available at https://www.nist.gov/ctl/pscr/commercialization/psiap-taba-demonstration.

[12] Tongal (2017) NIST The Future of Public Safety Technology. Available at https://tongal.com/project/TheFutureofPublicSafetyTechnology/\#tab-brief.

[13] National Institute of Standards and Technology (2017) 2017 Virtual Public Safety Test Environment Challenge. Available at https://www.nist.gov/ctl/pscr/openinnovation-prize-challenges/past-prize-challenges/2017-virtual-public-safety-test.

[14] National Institute of Standards and Technology (2018) 2018 Differential Privacy Synthetic Data Challenge. Available at https:/www.nist.gov/ctl/pscr/openinnovation-prize-challenges/past-prize-challenges/2018-differential-privacysynthetic.

[15] National Institute of Standards and Technology (2018) 2018 Virtual Reality Heads-Up-Display Navigation Challenge. Available at 
https://www.nist.gov/ctl/pscr/open-innovation-prize-challenges/past-prizechallenges/2018-virtual-reality-heads-display.

[16] National Institute of Standards and Technology (2018) 2018 The Unlinkable Data Challenge. Available at https://www.nist.gov/ctl/pscr/open-innovation-prizechallenges/past-prize-challenges/2018-unlinkable-data-challenge.

[17] National Institute of Standards and Technology (2018) 2018 Unmanned Aerial Systems Flight and Payload Challenge. Available at https://www.nist.gov/ctl/pscr/open-innovation-prize-challenges/past-prizechallenges/2018-unmanned-aerial-systems-flight.

[18] National Institute of Standards and Technology (2019) 2019 Expanding the SIM Card Use for Public Safety Challenge. Available at https://www.nist.gov/ctl/pscr/open-innovation-prize-challenges/past-prizechallenges/2019-expanding-sim-card-use-public.

[19] National Institute of Standards and Technology (2019) 2019 Haptic Interfaces for Public Safety Challenge. Available at https://www.nist.gov/ctl/pscr/openinnovation-prize-challenges/past-prize-challenges/2019-haptic-interfaces-publicsafety.

[20] National Institute of Standards and Technology (2019) 2019 Tech to Protect Challenge. Available at https://www.nist.gov/ctl/pscr/open-innovation-prizechallenges/past-prize-challenges/2019-tech-protect-challenge.

[21] Lafayette Group (2020) ASAPS Challenge: Automated Streams Analysis for Public Safety. Available at https://www.asapschallenge.ai/.

[22] National Institute of Standards and Technology (2020) 2020 CHARIoT Challenge: Advancing First Responder Communications. Available at https://www.nist.gov/ctl/pscr/open-innovation-prize-challenges/current-andupcoming-prize-challenges/2020-chariot.

[23] National Institute of Standards and Technology (2020) 2020 Differential Privacy Temporal Map Challenge. Available at https://www.nist.gov/ctl/pscr/openinnovation-prize-challenges/current-and-upcoming-prize-challenges/2020differential.

[24] National Institute of Standards and Technology (2020) 2020 Enhancing Computer Vision for Public Safety Challenge. Available at https://www.nist.gov/ctl/pscr/open-innovation-prize-challenges/current-andupcoming-prize-challenges/2020-enhancing.

[25] Capital Consulting Corporation (2020) First Responder UAS Endurance Challenge. Available at https://www.firstresponderuaschallenge.org/index.php\#about.

[26] U.S. Bureau of Labor Statics (2021) CPI Inflation Calculator. Available at ${ }^{1}$ (https://www.bls.gov/data/inflation calculator.htm).

[27] National Institute of Standards and Technology (2018) Past Funding Opportunities. Available at https://www.nist.gov/ctl/pscr/fundingopportunities/past-funding-opportunities.

[28] Cason, T.N., Masters, W.A. and Sheremeta, R.M., 2018. Winner-take-all and proportional-prize contests: theory and experimental results. Journal of Economic Behavior \& Organization. 
[29] United States Census Bureau (2021) North American Industry Classification System. Available at https://www.census.gov/naics/?99967.

[30] Bureau of Economic Analysis (2018) Regional Input-Output Modeling System (RIMS II) User's Guide. Available at https://www.bea.gov/resources/methodologies/RIMSII-user-guide.

[31] Bureau of Economic Analysis (2018) Industry List B. RIMS II 64 Aggregate Industry Codes. Available at https://apps.bea.gov/regional/rims/rimsii/download/64IndustryListB.pdf. 